\title{
Öğretmen Adaylarının Bilimsellik Değer Algılarının Karakter Ĕ̆itimi Programı Yoluyla Geliştirilmesi: Bir Eylem Araştırması
}

\section{Development of Teacher Candidates' Perceptions of Scientific Value Through Character Education Program: An Action Research}

\author{
Hafize ER TÜRKÜRESIN \\ Dumlupınar Üniversitesi, Eğitim Fakültesi, Türkçe ve Sosyal Alanlar Bölümü, Sosyal Bilgiler Eğitimi A.B.D., \\ Kütahya \\ e-posta: hafize.er@dpu.edu.tr
}

Atıf: Er Türküresin, H. (2018). Öğretmen Adaylarının Bilimsellik Değer Algılarının Karakter Eğitimi Programı Yoluyla Geliştirilmesi: Bir Eylem Araştırması. E-Kafkas Eğitim Araştırmaları Dergisi, 5(2), 1-19.

Gönderi Tarihi: 17-01-2018

Kabul Edilme Tarihi: 17-05-2018

DOI: $10.30900 /$ kafkasegt.380179

\section{Özet}

$\mathrm{Bu}$ araştırmada sosyal bilgiler öğretmen adaylarına yönelik hazırlanan bir karakter eğitimi programının bilimsellik değer algısına olan etkisini belirlemek amaçlanmıştır. Araştırma, 2015-2016 eğitim öğretim yılında Kütahya Dumlupınar Üniversitesi Eğitim Fakültesi Sosyal Bilgiler Öğretmenliği Bölümü’nde öğrenim gören 21 gönüllü öğrenci ve gönüllü öğrenciler arasından seçilen 5'i kız 6'sı erkek olmak üzere toplam 11 odak öğrenciyle gerçekleştirilmiştir. Araştırma kuram ve uygulamayı birleştirmek, bunun yanında belirlenen değer alanlarında gelişim ve değişim sağlayabilmek adına eylem araştırması biçiminde desenlenmiştir. Araştırma verileri; video kayıtları, yarı yapılandırılmış görüşmeler, araştırmacı ve öğrenci günlükleri, öğrencilere ait el yapımı ürünler ve "Bilimsellik Ölçeği” kullanılarak toplanmıştır. Araştırmanın nicel verileri SPSS 20.0 programı ile çözümlenmiş ve yorumlanmıştır. Nitel veriler ise, NVivo 9.0 programı kullanılarak betimsel analiz tekniğiyle çözümlenmiş ve elde edilen bulgular araştırma sorularına bağlı olarak yorumlanmıştır. Analiz sonuçlarına göre karakter eğitimi programına katılan öğrencilerin "Bilimsellik" değer algılarının pozitif yönde değiştiği sonucuna ulaşılmıştır. Nitel verilerden elde edilen bulgular nicel verileri desteklemektedir.

Anahtar Kelimeler: bilimsellik, değer, karakter eğitim programı.

\begin{abstract}
The purpose of this study is to determinate the effect of the character education program on scientific value. The research is conducted with 21 participants who were students in Dumlupınar University, Social Studies Teacher Education Program in 2015-2016 school year and 6 boys and 5 girls were chosen as focal students among them. The action research method, which allows researchers to use theory and practice together, was implemented in order to improve pre-determined characteristics. The data gathered from video recordings, semi-structured interviews, researcher and participant journals, students' outputs and "Being Scientific Scale". SPSS was used for analyizng the quantitative data and NVivo was used for analyizing qualitative data. The results from quantitative data show that the students scores increased in all scales except in "Respect to differences scale". Findings from qualitative data support quantitive findings.
\end{abstract}

Key Words: scientific, values, character training program.

\section{GİRiş}

Weber'le birlikte ünlenen ve günümüzde çokça kullanılan değer kavramı, farklı alanlarda insanların üzerinde anlaştığı veya anlaşmaya çalıştığı bir kavramdır. Literatürde genel olarak değerler; arzu edilen ve olması istenilen, kişilerin hayatlarına kılavuzluk edip onları yönlendiren, önem dereceleri farklı, durumlar ötesi amaçlar olarak kullanılmaktadır (Bacanlı, 2002; Halstead, 1996; Rokeach, 1973; Şişman, 2002). Değerler istekleri, tercihleri ve bireyin arzularını yansıtır, yani bir şeyin istenilen ya da tercih edilmeyen olduğu yönündeki inançlardır (Güngör, 1993). Değerler, neyin doğru ve neyin yanlış, neyin iyi ve neyin kötü olduğunu belirlemeye yarayan ölçütlerdir (Şişman, 2002). Öncül (2000) ise değer kavramını; bir nesneye, varlığa, ruhsal, ahlaksal, toplumsal açıdan tanınan önem ya da üstünlük derecesi olarak tanımlamıştır. Diğer bir tanıma göre ise değer; bir şeyin aynı türden şeyler arasındaki yerine, konumuna bizlerin yüklediği anlamlardır (Ekşi ve Katılmış, 2014).

Değerler bireylerin ve toplumun karşılıklı olarak birbirlerini etkilemesi sonucunda ortaya çıkmaktadır (Gömleksiz, 2007; Ural, 1997). Değerler bizlere neyi nasıl yapacağımızı kesin olarak ifade etmezler ancak yapılacak olan şeyler için yol gösterirler ve beşeri var oluşun anlamına önemli bir katkıda bulunurlar (Harcar, 
2005; Özensel, 2003; Tozlu ve Topsakal, 2007). Bu tanımlardan yola çıkıldığında değerlere ilişkin ortak iki nokta göze çarpmaktadır; Birincisi, tanımların anlamlarda, sonuçlarda, işlev ve hedeflerde yoğunlaşmış olmasıdır. İkincisi ise, değerlerin, tercihler ya da öncelikler olarak görülmesidir.

Okullarda değer eğitimi, daha çok işlev ve hedeflere yönelik olarak belirlenmekte ve belirli bir program dâhilinde öğrencilere kazandırılmaya çalışılmaktadır. Okul sürecinde değer ve ahlak eğitiminin ilk amacı okuldaki eğitim etkinliklerini başarıyla tamamlayabilmek, bireyi yüceltmek ve bireyin topluma uygun davranışlar sergilemesine yardım etmektir (Yavuzer, 1999). Okullar çağın getirdiği olumsuz olay ve durumlara karş1 öğrencilerin iyi ve doğru tercihler yapabilmesi için onlara yol gösterebilmeli ve yeni alternatifler oluşturmasına yardımcı olmalıdır. Bu nedenle öğrenim çağının her basamağındaki bireylerin uygun ahlaki kararlar almasında ve bu kararlar doğrultusunda davranışlar gerçekleştirmesinde okullarının önemli bir yeri bulunmaktadır (Dilmaç, 2007).

Toplumun eğitimden beklediği, bireylere bilgi ve beceri kazandırmanın ötesinde bireyin hızla değişen dünyaya uyum sağlayabilmesi ve ahlaki olarak kendini geliştirmesidir (Ada ve Ünal, 2000). Bu açıdan okulların tek görevi bilgi ve beceri kazandırmak değil, karakter eğitimi açısından da temel insani değerleri öğretmektir (Ada, Baysal ve Korucu, 2005). Karakter eğitiminin temel amacı ise çocukluk döneminde anlayışlı, ahlaki değerleri olan, üretken ve ilgili; gençlik çağında ise potansiyellerini en iyisini yapmak için kullanan, hayatının amacını belirleyerek buna göre yaşayan iyi bireyler yetiştirmektir. Etkin karakter eğitimi, tüm öğrencilerin bir beklentisi olmadan kendi potansiyellerini keşfetmelerini sağlamak amacıyla sınıf ve okul ortamı oluşturulmasını gerekli kılmaktadır (Battistich, 2008). Bireyler, karakteri oluşturan değerlere doğuştan sahip değildir. Karakteri oluşturan değerlerden hangisinin doğruyu, hangisinin yanlışı ifade ettiğini bilmek deneyim gerektirir. Bireyin nasıl bir insan olacağı doğduktan sonraki yaşam tecrübelerine bağlıdır. Okullarda doğru ve bilinçli bir karakter eğitimi bu yüzden hayati önem taşımaktadır (Montagu, 2000). Şüphesiz çocukların karakter gelişiminin tek sorumlusu okullar değildir ancak çocukların okulda geçirdiği zaman dilimi düşünüldügünde okulların sorumluluğu bir kez daha göze çarpmaktadır (Ryan, 1992).

Okulların karakter eğitimindeki rolü üzerine uzlaşma olduğu düşünülse de bunu gerçekleştirmek için gerekli olan program ve yöntemler hakkında uzlaşmaya varılamamıştır (Milson ve Mehling, 2002). Ancak Türk Milli Eğitimi'nin amaçlarında karakter ve kişilik gelişimine yer verilmektedir. Türk Milli Eğitimi'nin genel amaçlarından biri; "Fertlerin beden, zihin, ahlak, ruh ve duygu bakımından dengeli ve sağlıklı şekilde gelişmiş̧ bir kişiliğe ve karaktere, hür ve bilimsel düşünme gücüne, geniş bir dünya görüşüne sahip, insan haklarına saygıll, kişilik ve teşebbüslere değer veren, topluma karşı sorumluluk duyan, yapıcı, yaratıcı ve verimli kişiler olarak yetiştirmektir”(MEB, 2005). Bu bakımdan karakter eğitiminin programlar aracıllğıyla gerçekleştirilmeye çalışıldığı söylenebilir fakat hala eksikliklerin olduğuna inanılmaktadır (Kıncal, 1999). Yapılandırmacılık yaklaşımıyla birlikte uygulamaya konulan 2004 sonrası programla birlikte öğrencilerin kişilik gelişimlerine önem verilmiştir. 2004'e kadar uygulanan programda ise öğrencilerin bilişsel ve zihinsel gelişimlerine önem verilmekte ancak kişilik gelişimlerine yeteri kadar değinilmemektedir (Kılınç, 2011). Yenilenen programla birlikte değer ve karakter eğitimine verilen önem artmış ve bu alanda yapılan çalışmaların sayısında gözle görülür bir artış yaşanmıştır (S1lay, 2010).

Son zamanlarda yapılan araştırmalar, öğretmen yetiştiren kurumların öğretmenleri karakter eğitimine hazırlaması yönünde desteklediklerini göstermektedir. Ancak üniversite düzeyinde karakter eğitimi için gerekli olan yöntem ve uygulamalar hakkında ortak bir anlayış söz konusu değildir (Jones, Ryan ve Bohlin, 1998; Milson, 2000). Thornton' a (1991) göre temel amacı iyi vatandaş yetiştirmek olan sosyal bilgiler öğretmenleri, öğrencilere karakter eğitimi vermek için ideal öğretmenler olarak görülebilir. Ayrıca yeni Sosyal Bilgiler Öğretim Programı bireylere bilgi ve beceri öğretiminin yanında değer öğretimi verilmesi gerekliliğine vurgu yapmaktadır. Bu gibi nedenlerle sosyal bilgiler öğretmen adayları için karakter eğitimi uygulamaları değerli görülmektedir. Bu eğitim basamağında öğretmen adaylarından beklenen çağa ayak uyduran, 21. yy beceriyle donanmış, bağımsız araştırma yapabilme becerisine sahip bireyler olarak yetişmeleridir.

Sosyal Bilgiler Dersi Öğretim Programı'nda; "Adil olma, aile birliğine önem verme, akademik dürüstlük, bağımsızlık, barış, bayrağa ve İstiklâl Marşı'na saygı, bilimsellik, çalışkanlık, dayanışma, doğa sevgisi, doğal çevreye duyarlılık, duygu ve düşüncelere sayg, dürüstlük, estetik, farklılıklara saygı, hak ve özgürlüklere saygl, hoşgörü, külttürel mirasa duyarlılık, misafirperverlik, sağlıklı olmaya önem verme, sorumluluk, tarihsel mirasa duyarlılık, temizlik, Türk büyüklerine saygı, vatanseverlik ve yardımseverlik" olmak üzere toplam 26 değerin öğrencilere doğrudan kazandırılması amaçlanmıştır (MEB, 2005). Bu değerleri öğrencilere kazandırmanın yollarından biri karakter eğitimidir. Öğrencilere belirli değerlerin kazandırılmasının amaçlandığı karakter eğitimi, değer eğitimi şemsiyesi altında bir uygulama alanıdır (Kirschenbaum, 1995). Bilindiği gibi karakter eğitimi, değerler eğitimi kavramı altında okullarda uygulanmaktadır. Okullarda değer eğitimi ağırlıklı olarak ilkokul ve ortaokul düzeyinde verilse de özellikle bilimsellik gibi üst bilişsel yeterlilik 
isteyen değerlere ait kazanımların üniversite düzeyinde yoğunlaşması gerekmektedir. Eğitim fakültelerinde bu amaçla (Bilimsel Araştırma Yöntemleri gibi) farklı dersler olmasına rağmen özellikle sınıflarda kişi sayısının fazla olması, ders süresinin yetersiz olması gibi nedenlerle öğrenciler yeterince uygulama yapma imkânı elde edememektedir.

Bu bağlamda araştırmada;

- Karakter eğitimi programı, öğretmen adaylarının bilimsellik değer algılarını etkilemekte midir?

- Karakter eğitimi programı, öğretmen adaylarının bilimsellik değeri kazanımlarını nasıl etkilemiştir? Sorularına cevap aranmıştır.

\section{YÖNTEM}

Sosyal bilgiler öğretmen adaylarına yönelik hazırlanan karakter eğitimi programı yoluyla öğretmen adaylarının bilimsellik değer algılarının geliştirilmeye çalışıldığı bu çalışmada nitel araştırma yöntemlerinden eylem araştırması deseni kullanılmışır. Eylem araştırması öğretimin niteliğini artırmak ve sorunları tespit etmek amacıyla okul ve sınıf ortamında yapılan çalışma süreci olarak tanımlanmaktadır (Hensen, 1996; McTaggart, 2002). Bir başka tanıma göre eylem araştırması, kuruluşlarda bizzat uygulayıcının içinde olduğu, doğrudan kendisinin ya da bir araştırmacı ile birlikte gerçekleştirdiği ve uygulama sürecine ilişkin sorunların ortaya çıkarılması ya da hali hazırda ortaya çıkmış bir sorunu anlama ve çözmeye yönelik sistematik veri toplamayı ve analiz etmeyi amaçlayan bir araşıırma yaklaşımı olarak tanımlanmıştır (Yıldırım ve Şimşek, 2008). Literatürde eylem araştırması yöntemiyle ilgili farklı modeller bulunmaktadır. Bu modellerde genellikle araştırmaya katılanların takip edecekleri adımlar açıklanmaktadır. Araştırma adımları; bazı küçük değişikliklere rağmen problemin oluşturulması, verilerin toplanması ve analiz edilmesi, verilere dayalı uygulama planlarının oluşturulması ve uygulanması, sonuçların incelenmesi ve problemlerin tekrar oluşturulması gibi basamaklardan oluşmaktadır (Çepni, 2012).

\section{Çalış̧ma grubu}

Nitel araştırmaların doğası gereği ulaşılan sonuçlar ve çalışılan konu duruma özgüdür ve bu nedenle katılımcılar amaçlı örnekleme yöntemiyle belirlenmektedir (Creswell, 2013). Amaçlı örneklem yöntemi ile fazlaca bilgiye sahip olduğu düşünülen durumların derinlemesine çalışılması mümkündür (Patton, 1990). Bu sebeple araştırmada katılımcılar amaçlı örnekleme yöntemlerinden ölçüt örneklem yöntemiyle belirlenmiştir. Araştırmanın katılımcıları sosyal bilgiler öğretmenliği 2/B şubesinin 21 gönüllü öğrencisidir. 12 kız ve 9 erkek öğrenciden oluşan ikinci sınıf öğrencileri 2014-2015 eğitim öğretim yılı bahar döneminden beri aynı sınıfta okumaktadırlar. Araştırmaya katılan öğrencilerin kişisel bilgileri Tablo 1' de verilmiştir.

Tablo 1.

Katılımcıların özellikleri

\begin{tabular}{lllll}
\hline & Öğrenci Özellikleri & f & \% \\
\hline \multirow{2}{*}{ Cinsiyet } & Kız & 12 & 57,1 \\
& Erkek & 9 & 42,9 \\
\hline \multirow{4}{*}{ Yaş } & $17-19$ & 6 & 28,6 \\
& $20-22$ & 11 & 52,4 \\
& $21-23$ & 2 & 9,5 \\
& 24 ve üstü & 2 & 9,5 \\
\hline \multirow{4}{*}{ Yaşanıllan Bölge } & Akdeniz & 2 & 9,5 \\
& Ege & 4 & 19,0 \\
& Marmara & 7 & 33,3 \\
& İc Anadolu & 6 & 28,6 \\
& Güneydoğu Anadolu & 2 & 9,5 \\
\hline \multirow{2}{*}{ Ortalama (AGNO) } & $1.00-1.99$ & 4 & 19,0 \\
& $2.00-2.99$ & 16 & 76,2 \\
& $3.00-4.00$ & 1 & 4,8 \\
\hline
\end{tabular}

Tablo 1'de özellikleri yansıtılan öğrencilere ait kişisel bilgiler ve araştırmacının temel aldığ kıstaslar dikkate alınarak geçerlik komitesi üyelerinin de onayı alınarak on bir öğrenci odak olarak belirlenmiş̧tir. Odak öğrencilerin belirlenmesi aşamasında herhangi bir ölçekten yararlanılmamış, ölçütler belirlenmiştir. Kazandırılmak ya da geliştirilmek istenen değerler doğrultusunda belirlenen ölçütler öğrencilerin akademik başarı puanları, cinsiyet ve gönüllülük unsurlarıdır. Akademik başarı ölçütü olarak öğrenciler üst-orta ve alt 
başarı ortalamasına göre gruplandırılmıştır. Bu kıstaslar sonucunda 5'i kız, 6'sı erkek olmak üzere 11 odak öğrenciyle çalışma gerçekleştirilmiştir. Ayrıca süreçte her öğrenciye bir kod isim verilmiş ve doğrudan alıntılarda bu isimler kullanılmıştır.

Tablo 2.

Odak ögrenciler

\begin{tabular}{ll}
\hline Temsili Ö̆̆renci Adı (Kod İsim) & Ortalama \\
\hline Odak Ö̆̆renciler & \\
\hline 1. Canan & 1,64 \\
\hline 2. Asiye & 2,42 \\
\hline 3. Tülin & 2,17 \\
\hline 4. Gonca & 2,30 \\
\hline 5. Ebru & 2,07 \\
\hline 6. Ayhan & 3,48 \\
\hline 7. Sabri & 2,02 \\
\hline 8. Arif & 1,79 \\
\hline 9. Mahmut & 1,98 \\
\hline 10. Enes & 1,78 \\
\hline 11. Üzeyr & 1,52 \\
\hline
\end{tabular}

\section{Veri toplama araçlart}

Eylem araştırmalarında verilerin birden fazla kaynaktan toplanması (ölçekler, görüşme, gözlem, fotoğraflar vb.) verilere ve olaylara farklı açılardan bakmayı mümkün kıldığından araştırmayı güçlü hale getirmektedir (Johnson, 2002). Bu nedenle araştırmada veri çeşitliğini sağlamak amacıyla çeşitli nitel ve nicel veri toplama yöntemleri kullanılmıştır. Araştırmanın nicel verileri "Bilimsellik Ölçeği" ile nitel verileri ise yarı yapılandırılmış görüşmeler, öğrenci ürünleri ve öğrenci-araştırmacı günlükleri ile toplanmıştır. Yarı yapılandırılmış görüşme tekniği, özel bir konuda derinlemesine soru sorma ve cevap yeterli olmadığında ya da açık olmadığında tekrar soru sorup durumu daha açık hale getirip cevapları tamamlama firsatı sağlaması açısından avantajlı bir tekniktir (Çepni, 2012). Araştırmanın nicel verilerinin toplandığı "Bilimsellik Değeri Ölçeği” Katılmış (2010) tarafından geliştirilmiştir. Ölçek, üç boyutlu ve 21 maddeden oluşmaktadır. Ölçeğin üç alt boyutunu oluşturan Merak Etme ve Eleştirel Bakabilme boyutunda 10 soru, Kanıt Kullanma ve Etik boyutunda 7 soru, Özgürlük boyutunda ise 4 soru bulunmaktadır. Katılmış (2010) tarafından geliştirilen Bilimsellik Ölçeğinin tamamının ve her bir alt boyutunun güvenirliğini ölçmek için Cronbach Alpha değerleri hesaplanmıştır. Cronbach Alpha değerleri; Merak Etme ve Eleştirel Bakabilme boyutu için 0.93, Kanıt Kullanma ve Etik boyutu için 0.91, Özgürlük boyutu için 0.79, Bilimsellik Ölçeğinin tamamı için ise 0.95'tir. Bilimsellik Ölçeği beşli likert tipi bir ölçek olup, ölçekteki maddelerin seçenekleri "Kesinlikle Katılmıyorum, Katılmıyorum, Kararsızım, Katılıyorum ve Kesinlikle Katılıyorum" şeklindedir. Ölçeğe verilen yanıtlar "Kesinlikle Katılmıyorum" bir puan, "Katılmıyorum" iki puan, "Kararsızım" üç puan, "Katılıyorum" dört puan ve "Kesinlikle Katılıyorum" ise beş puan olarak puanlanmıştır. Öğretmen adaylarından ölçekte yer alan maddeleri benimseme derecelerine göre puanlamaları istenmiştir. Buna göre ölçekten alınabilecek en düşük puan $21 \times 1=21$, ortalama puan $21 \times 3=63$ ve en yüksek puan $21 \times 5=105$ 'tir.

\section{Verilerin toplanmast ve analizi}

Araştırmada nicel verilerin toplanması amacıyla belirlenen değerle ilgili katılımcılara "Bilimsellik Değer Ölçeği” uygulanmıştır. Araştırma sürecinin başında ve sonunda olmak üzere iki kere uygulanan ölçekler SPSS programı kullanılarak analiz edilmiştir. Araştırma probleminin yanıtlanması amacıyla yapılan grup içi karşılaştırmalarda parametrik olmayan testlerden olan Wilcoxon İşaretli Sıralar Testi uygulanmıştır. Wilcoxon İşaretli Sıralar Testi (signedrank) testi parametrik istatistikte alakalı örneklemler için yapılan bağımlı iki örnek ttestinin nonparametrik analizdeki karşılığı kabul edilmektedir (Kalaycı ve diğ., 2005). Araştırma verileri normal dağılım göstermediği için parametrik olmayan testler uygulanmıştır. Araştırmada kullanılan istatistiksel çözümlemelerde anlamlılık düzeyi 0.05 olarak kabul edilmiştir. Wilcoxon işaretli sıralar testi eşleştirilmiş veriler arasındaki farklılıkların yönüyle ilgilenmekte ve dağılımın aynı olup olmadığını test etmektedir (Çepni, 2012). Çeşitli ölçme araçlarının kullanıldığı araştırmada toplanan nitel veriler betimsel analiz yöntemiyle analiz edilmiştir. Doğrudan alıntıların olduğu kısımlarda öğrencilere temsili isim verilmiştir. Betimsel analiz yönteminin kullanıldı̆̆ı bu araştırmada veri analizi aşamasında izlenen sıra kısaca aşağıdaki gibidir:

- Veri toplama araçlarından elde edilen verilerin her birine kendi arasında numara ve isim verilmiştir. 
- Veriler kendi arasında anlamlı bölümlere ayrılarak sınıflandırılmıştır.

- Veriler NVivo 9.0 nitel veri analizi paket programına yüklenmiş, tüm veriler okunmuş ve kodlanmıştır.

- Oluşturulan kodlar daha önce belirlenen temalara yerleştirilmiş ve yorumlanmıştır.

\section{Eylem arașttrmasında geçerlik ve güvenirlik}

Eylem araştırmalarında geçerlik ve güvenirlik, nicel araştırmalara göre farklı biçimde gerçekleştirilmektedir. Nicel araştırmalarda var olan iç geçerlik, dış geçerlik, güvenirlik ve nesnellik eylem araştırmalarında aynı şekilde uygulanamaz. Bunun ana nedeni eylem araştırmalarının yerel temelde gerçekleştirilmesi ve verilerin kendine özgü bağlamının olmasıdır. Bu ölçütler yerine eylem araştırmalarında inandırıcılık, transfer edilebilirlik, güvenilmeye layık olma ve onaylanabilirlik ölçütleri, eylem araştırmalarının geçerliliğini test etmektedir (Mills, 2003).

Araştırmanın inandırıcıllğını artırabilmek için araştırma ortamında uzun süreli bulunma, uzman ve meslektaş görüşü alma, veri çeşitlemesi sağlama gibi yollara başvurulabilir. Bu araştırmada da araştırmanın inandırıcılığını artırabilmek için veri çeşitlemesi yoluna gidilmiş farklı veri toplama araçları kullanılarak inandırıcııı artırılmaya çalışılmışıı. Aynı zamanda araştırmayı yakından takip eden üç kişiden oluşan geçerlik komitesi ve iki kişiden oluşan alan uzmanından yardım alınarak, ortaya çıkan kararlara göre araştırmaya yön verilmiştir. Geçerlilik komitesi, araştırmayı yakından takip eden aynı üniversitede çalışan üç tez izleme komitesi üyesidir. Transfer edilebilirlik ölçütü için ise problem durumu ile ilgili ayrıntılı betimsel veri toplama ve raporlaştırma yollarına başvurabilir. Araştırmada transfer edilebilirlik ölçütü sağlanması için ayrıntılı betimleme yoluna gidilmiş, araştırma sürecine yer verilmiş, doğrudan ve dolaylı alıntılar, fotoğraflar ve öğrenci ürünleriyle yapılan bu betimleme zenginleştirilmeye çalışılmıştır. Yine araştırmanın benzer araştırmalara transfer edilebilmesi için çalışma raporunda mümkün olduğunca ayrıntıya yer verilmiştir.

\section{Eylem araştırması süreci}

Araştırmacının uygulamalara dâhil olduğu ve katılımcı eylem araştırması sürecinin takip edildiği bu araştırmada ilk olarak problem durumları tespit edilmeye çalışılmıştır. Problemlerin tespitinden sonra araştırmacı tarafından yapılan planlar, araştırmanın kuramsal olarak sınanmasına dayanmaktadır. Araştırmacı eylem araştırması süresince, geçerlik komitesi üyeleriyle toplantılar yapmış ve yapılan toplantılarda alınan kararlar doğrultusunda etkinliklerin sonlandırılmasına ya da devam ettirilmesine karar verilmiştir. Araştırma döngüsü istenen kazanımlara ulaşıncaya kadar aynı şekilde devam etmiştir. Patterson ve Shannon'a (1993) göre eylem araştırması beş basamaktan oluşmakta ve bu basamakların ilk adımını çalışmak istenen konunun, durumun ya da problemin belirlenmesi oluşturmaktadır. $\mathrm{Bu}$ sebeple eylem araştırması süreci tasvir edilmeden önce araştırma problemlerinin belirlenmesi gerekmektedir. Karakter eğitimi programında (KEP) "Bilimsellik" değerine yer verilme nedenini ise eylem planları hazırlanmadan önce ana bilim dalında görevli öğretim elemanlarıyla yapılan görüşmeler ve incelenen öğrenci ürünleri oluşturmaktadır. Yapılan görüşmelerde öğretim elemanları, öğrenciler tarafindan hazırlanan araştırma ödevlerinin içerik ve şekil olarak eksik olduğu ve üniversite düzeyinde hazırlanan araştırmaları yansıtmadığını belirtmişlerdir. Araştırmacı bu nedenle öğretim elemanlarından birkaç örnek ödev isteyerek problemi görmeye çalışmıştır. Problemleri tespit etmeye çalışan araştırmacı bilimsellik değeri altında, araştırma yöntemleri ve sürecine dair etkinlikler yapmaya karar vermiştir. Öğrencilerin çalışmalarında gözlenen eksiklere "Bulgular" bölümünde yer verilmiştir. Araştırma problemi tespit edildikten sonra eylem planlarını hazırlama aşamasına geçilmiştir. Eylem planları hazırlama aşamasına geçilmeden önce alan yazında yapılan çalışmalar incelenmiş ve eylem planlarının taslağı oluşturmaya çalışılmıştır. Taslak planlar 2014-2015 eğitim öğretim yılı yaz döneminde hazırlanmıştır.

Tablo 3.

Etkinlik planı așamaları

\begin{tabular}{ll}
\hline 1. Konu & 7. Görevliler ve Sorumlulukları \\
\hline 2. Tema & 8. Malzemeler \\
\hline 3. Amaç ve Tanım & 9. Uygulamanın Sağlayacağı Faydalar \\
\hline 4. Tavsiye Edilen Uygulama Zamanı ve Süre & 10. İş Birliği Yapılacak Kurum ya da Gruplar \\
\hline 5. Yöntem ve Teknikler & $\begin{array}{l}\text { 11. Uygulamada Karşılaşılabilecek Sorunlar ve Çözüm } \\
\text { Önerileri }\end{array}$ \\
\hline 6. Uygulama Basamakları & 12. Sürdürülebilirlik Tedbirleri \\
\hline
\end{tabular}

Yukarıdaki basamaklar takip edilerek literatüre ve araştırma problemlerine dayanarak hazırlanan eylem planları eğitim öğretim yılı başlamadan önce üç kez geçerlik komitesi üyelerinin onayına sunulmuştur. Geçerlik komitesinin görüş ve önerileri doğrultusunda etkinlikler gerçekleştirilmeden eylem planları üzerinde tartışılmış ve eylem planlarına son şekli verilmiştir. Geçerlik komitesi üyeleriyle yapılan görüşmeler etkinlikler 
sonlandırılıncaya kadar devam etmiştir. Eylem araştırmasının doğasında olan bu durum bazen ders saatinden, bazen araştırma ortamından ve öğrencilerden ya da yeni bir durumla karşılaşıllmış olmasından kaynaklanmaktadır. Yaşadığı bu problemlere bulgular aşamasında yer veren araştırmacı, karşılaştığı problemlere yönelik geliştirdiği çözüm önerilerinden de bahsetmiş̧ir. Eylem araştırması sürecinin son aşaması raporlaştırma ve araştırma sonuçlarının bulgular doğrultusunda tartışılıp öneriler geliştirmesi şeklindedir (Mills, 2003).

\section{BULGULAR}

Nicel verilerden elde edilen bilimsellik değerinin gelişimine iliş̧kin bulgular

Araştırmanın birinci alt problemi:"Karakter eğitimi programı, öğretmen adaylarının bilimsellik değer algılarını etkilemekte midir?" biçiminde ifade edilmiştir. Bu soruya yanıt aramak amacıyla geliştirilen "Bilimsellik Değeri Ölçeği" sürecin başında ve sonunda olmak üzere iki defa öğretmen adaylarına uygulanmış ve öğretmen adaylarının aldıkları puanlar arasındaki farklılaşmaya bakılmıştır. Bilimsellik değerinin ön test ve son test ölçüm sonuçları arasındaki farkın anlamlı olup olmadığını belirlemek için yapılan Wilcoxon İşaretli Sıralar Testi sonuçları Tablo 4' te verilmiştir.

Tablo 4.

Bilimsellik değerinin öntest ve sontest ortalama puanlarının Wilcoxon İşaretli Sıralar testi sonuçları

\begin{tabular}{|c|c|c|c|c|c|c|}
\hline & . & $\mathbf{N}$ & S.O & S.T & $\mathbf{Z}$ & $\mathbf{P}$ \\
\hline \multirow{4}{*}{$\begin{array}{l}\text { Bilimsellik } \\
\text { Değeri }\end{array}$} & Negatif Siralar & $4^{a}$ & 6,25 & 25,00 & \multirow{4}{*}{2,998} & \multirow{4}{*}{,003* } \\
\hline & Pozitif Siralar & $16^{b}$ & 11,56 & 185,00 & & \\
\hline & Eşit & $1^{\mathrm{c}}$ & & & & \\
\hline & Toplam & 21 & & & & \\
\hline
\end{tabular}

$\mathrm{P}<0.05^{*}$

Tablo 4 öğretmen adaylarının, "Bilimsellik Değer Ölçeği"nden almış oldukları Wilcoxon İşaretli Sıralar Testi sonuçlarını göstermektedir. Elde edilen bulgulara göre öğretmen adaylarının bilimsellik değerinden aldıkları ön test ve son test puanları arasında anlamlı farklılık bulunmaktadır. Söz konusu farklılık son test lehine gerçekleşmiştir. Buna göre süreç sonunda öğretmen adaylarının son test puanları artı̧ göstermiş̧tir $(\mathrm{Z}=2,998$; $\mathrm{p}<0.05)$.Yani bilimsellik değerine yönelik gerçekleştirilen etkinlikler sonrasında öğretmen adaylarının bilimsellik değer algılarında anlamlı bir artış olduğu ve yapılan uygulamaların etkili olduğu söylenebilir.

\section{Nitel verilerden elde edilen bilimsellik değerinin gelişimine ilişskin bulgular}

Araştırmanın nitel verileri NVivo 9.0 programı kullanılarak betimsel analiz yaklaşımına göre analiz edilmiştir. Öğretmen adaylarının bilimsellik değerine yönelik tutum ve davranışlarını olumlu yönde etkileyebilmek için eylem planları, alan yazın taraması ve öğrenci ihtiyaçları göz önünde tutularak hazırlanmışı̧ır. Yapılan planlama sonrasında, bilimsellik değeri altında kazandırılması düşünülen özellikler: "Kanıt Kullanma", "Etik" ve "Yaratıcılık biçiminde sınıflandırılmışıtır. Bu özelliklere yönelik gelişim anlatılmadan önce her değer alanı için öğretmen adaylarının algılarına yer verilmiştir.

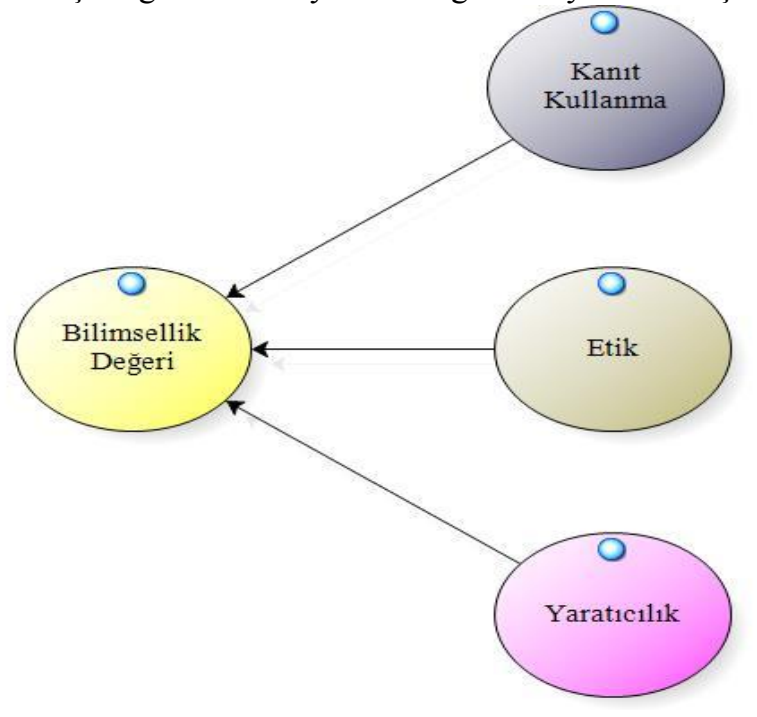

Şekil 1. Bilimsellik değerine ilişkin sinıflandırma.

Bilimsellik değeri kantt kullanmaya ilişskin bulgular

Bilimsellik değerine ilişkin ön bilgilerin yoklanmasının ardından gerçekleştirilen etkinlik ile öğrencilerin bilimsel çalışmalarda kanıt kullanmanın gerekliliğini fark etmeleri ve yapmış oldukları çalışmalarda 
kanıt kullanmalarını sağlamak amaçlanmıştır. Araştırmacı tarafından belirlenen bilimsellik değeri etkinliklerinden kanıt kullanmaya ilişkin kazanımlar Tablo 5’te verilmiştir.

Tablo 5.

Bilimsellik değgeri kanıt kullanmaya ilişkin kazanımlar

KAZANDIRILMAK İSTENEN DEĞER: BİLIMSELLİK

KAZANIMLAR

1. Kanıt kullanmanın ne demek olduğunu bilir.

2. Araştırmalarda kanıt kullanmanın gerekliliğini fark eder.

3. Çalışmalarında kanıt kullanır.

Araştırmacı, kazanımlara ilişkin belirlediği unsurlar doğrultusunda hazırladığı planın giriş etkinliği olarak etkinlikten bir hafta önceden öğrencilere verdiği raporları analiz ederek ve bu doğrultuda bir yönerge hazırlayıp öğrencilere dağıtarak derse başlamıştır. Öğrencilerin ön bilgilerinin tespit edilmeye çalışıldığ raporlardan örnekler aşağıdaki gibidir:

\title{
Karakter Eğitimi Nedir?
}

\begin{abstract}
Karakter, bir bireyin kendine özgü yapısıdır. Onu bașkalarından ayran ve bireyin davranıș biçimlerini belirleyen ana özelliktir. İnsanların çok yönlü özelliklerini gösteren davranıșlar bütünlüğ̈üdür. İnsanın kendisine, çevresindekilere, genel olarak topluma karșı tavirlarmı belirleyen karakter, toplumsal bir kavramdır. İyiyi bilme, iyiyi sevme ve iyiye ulaşma olarak da tanmlanur.

Ülke olarak yașadığımız sorunların temelinde yatan en önemli faktör nitelikli insan yetiștirme sorunudur. Sosyolojik bir değerlendirme olarak; toplumları bireyler olușturduğuna göre, bir toplumun kalite düzeyinin de o toplumda yașayan bireylerin kalitesinden veya kalitesizliğinden kaynaklandığmı söylemek yanlıș olmaz.

Günümüz eğitim-öğretim anlayıșında "öğretim" öne çkarılırken, "eğitim" boyutu ikinci planda değerlendirilmektedir. Eğitim kurumlarmda ve ailelerde bu durum dikkate alımmadığında amaçsız, vurdumduymaz, sorumluluk duygusu tașımayan, bencil toplulukların oluşması kaçmılmaz olacaktır.

Hem eğitimciler, hem de anne-babalar olarak çocuklarumıza doğruluk, sorumluluk, yardımseverlik, bașkalarma saygılı olma, çalıșkanhk, cesaret, ideal sahibi olma, kararhlık vb. evrensel değerlerin ögretilmesinin gerekliliği tartıșılmaz bir gerçektir. Ancak tartıṣma, bunun nasıl yapılacağı konusunda odaklanmaktadır.
\end{abstract}

Amerika Boston Üniversitesi'ndeki böyle bir merkezin, öğrencilerin ahlâk ve karakter gelişimiyle ilgili olarak yaptığı bir çalıșmada, çok sayıda öğretmen ve idarecinin fikirlerinden yararlanulmıs ve 100 maddelik bir tavsiye listesi hazırlamıștır. Her kültürden ögrencinin yararlanabileceği bu listedeki bazı maddeler kültürümüze adapte edilerek değiștirilmiștir.

Fotoğraf 1. Öğrencilerden Gül'ün etkinlik öncesi hazırladı̆̆ı rapor.

Etkinlik öncesinde örnek rapor olarak seçilen Gül'ün raporu dâhil olmak üzere diğer tüm ödevlerde eksik olan ortak noktalar hiçbirinde görsel olarak bir sistemin olmaması, tüm raporlarda kaynakça, alıntı, kapak vb. unsurların bulunmaması ve tek kaynaktan hazırlanmış olmasıdır. Sosyal Bilgiler Eğitiminde önemli amaçlardan biri olarak kabul edilen kanıt kullanma becerisi, bilimsellik değerinin altında görülebilir. Kanıt olarak kabul edilen birinci el kaynak (fotoğraf, günlük, buluntu vb.) ve ikinci el kaynakların (birinci el kaynaklara dayalı olarak hazırlanmış telif eserler) bilinmesi, kullanılması için gerekli olan ilk basamaktır. Araştırmacı bunu gerçekleştirebilmek için aşama aşama kanıt kullanmanın gerekliliği üzerine öğrencilerle birlikte çalışmalar yapmıştır. Bu kapsamda öğrencilere yapacak oldukları çalışmalarda kanıtlar bulabilecekleri veri tabanları Büyüköztürk (2010) tarafindan yayınlanan Bilimsel Araştırma Yöntemleri kitabında yer alan bilgiler kullanılarak anlatılmaya çalışılmıştır. Sonrasında ortak olarak belirlenen bir konu, seçilen veri tabanlarında deneme yapılarak öğrencilere gösterilmiştir. Yine aynı kapsamda üniversite kütüphanesinden ve üniversite kütüphanesi veri tabanlarından yararlanma yolları tartışılmış ve öğrencilerle birlikte uygulamalar yapılmıştır. Araştırmacı uygulama yaparken aynı zamanda öğrencilerin de uygulama yapmalarını sağlamaya çalışmıştır. Bunun için bir gün önceden öğrencilere bilgisayarlarıyla gelmelerini, bilgisayarı olmayan öğrencilerin ise kendi aralarında grup oluşturmalarını istemiştir.

Öğrenciler uygulama sonrasında öğrendiklerini aşağıdaki cümlelerle günlüklerine kaydetmişlerdir: 
Karakter ĕgitimini bilimsellik açısından değerlendirecek olursam makale yazmayı, kaynakçayl, intihali, veri tabanlarını, araştırma yapmayı ve araştırma yaparken kullanabileceğim yararlanabileceğim birçok olană̆ ögrendim (Ebru, 09.10.2015).

Bugünkü etkinliğin bana kazandırdı̆̆l en önemli katkl; makale yazma, makale okuma gibi şeyleri öğrenmek oldu. Araştırma yapabileceğim kaynakları, kapak, kaynakça nasıl yazılır, alıntı nasıl yapılır makale yazarken hangi aşamalardan geçilir bu gibi şeyleri öğrenmiş oldum. Önceden nerden araştırma yapabileceğimi bilmezken şimdi veri tabanlarını biliyorum (Enes, 09.10.2015).

Araştırmacı, öğrencilerle literatür tarama ve alıntı kuralları üzerinde çalışma yaptıktan sonra her öğrenciden bir sonraki hafta için bir konu belirlemesini ve bu konu hakkında literatür taraması yapıp bulduklarını flash belleğe kaydederek derse gelmesi gerektiğini söylemiştir. Bir sonraki haftanın amacı öğrencilerin yaptıkları çalışmaları rapor haline getirmelerine yardımcı olmak ve alıntı kurallarını öğretmeye çalışmaktır.

Araştırmacı, ilk olarak bir hafta önce işlenen konuları öğrencilere hatırlattıktan sonra her öğrenciden depoladıkları literatürleri bilgisayara aktarmalarını istemiştir. Yine aşama aşama "Araştırma Nasıl Raporlanır" hakkında bir yönerge hazırlayan araştırmacı bunu öğrencilere dağıtarak derse başlamıştır. Başlıktan, özete, alıntı kurallarından kaynakça oluşturmaya vb. diğer konulara değinerek her öğrencinin belirlediği konularda rapor hazırlamasına yardım eden araştırmacı etkinliğin ders saati içinde bitmemesi nedeniyle öğrencileri gruplara ayırmış ve belli saatlerde araştırmalarını rapor haline getirmeleri için onları yönlendirmiştir. Araştırmacı öğrencilerin bilimsel çalışmalarda kanıt kullanmanın önemine ilişkin gerçekleştirdiği etkinliklerle öğrencilerde farkındalık oluşturmayı ve bundan sonraki hazırlayacakları etkinliklerde kanıt kullanmalarını sağlamaya çalışmıştır. Nitekim odak olarak belirlenen öğrencilerden bir kısmı etkinlikler sonrası yapılan görüşmelerde kanıt kullanma konusundaki eksiklerini aşağıdaki biçimde yansıtmışlardır:

Araştırmacı: Evet Arif bugünkü yapılan etkinlik hakkındaki düşüncelerini alabilir miyim?

Arif: Tabi ki hocam ... Örneğin önceden bize bir araştırma konusu verildiğinde direkt gidip internetten bakıyordum. Ödevi raporlaştırırken de kafamıza göre yazıyorduk. Kuralları bilmiyorduk. Kaynakça göstermiyorduk. Alıntı kurallarına dikkat etmiyorduk (01.51"-02.09"). miydin?

Araştırmacl: Peki Mahmut bu programdan önce veri tabanlarl hakkında herhangi bir bilgiye sahip

Mahmut: Bilmiyordum hocam. Google akademiyi mesela ilk defa burada ögrendim... Artık ödev verildiğinde üniversitelerin veri tabanlarını kullanırım. Artık daha çok üniversite kütüphanesini kullanarak bazı şeylere erişmeye çalışlyorum (01.36"-01.46").

Araştırmacı: Tülin daha önce Scholar hakkında bilgin olduğunu ancak detaylı bilgi sahibi olmadı̆̆ını ifade ettin. Program sonrasında ne değişti?

Tülin: Google adresinin aslında bizim için nasıl değerli olup da bizim farkında olmadı̆̆ımızı öğrendim. Mesela, bir araştırma ya da ödev yapacağım zaman artık Blog denilen sayfalarda vakit harcamıyorum. Önceden bir konu verildiğinde direkt Google'a yazar orda çıkanları okur dururdum aralarında birkaç tane değerli bilgi vardır diye. Bu da benim için boşuna zaman kaybı olurdu (0.37-0.55").

Araştırmacı, son olarak öğrencilerin kanıt kullanma konusunda öğrendiklerini yapmış oldukları çalışmalara yansıtıp yansıtmadıklarını görmek amacıyla öğrencilere "Cumhuriyetten Günümüze Eğitim Politikaları" konulu yeni bir araştırma konusu vermiş ve yine hazırlanan raporları ders başlamadan üç gün önce kendisine ulaştırılmasını istemiştir. Eğitim sonrası öğrencilerin ulaştırdıkları raporlardan örnekler aşağıdaki gibidir: 


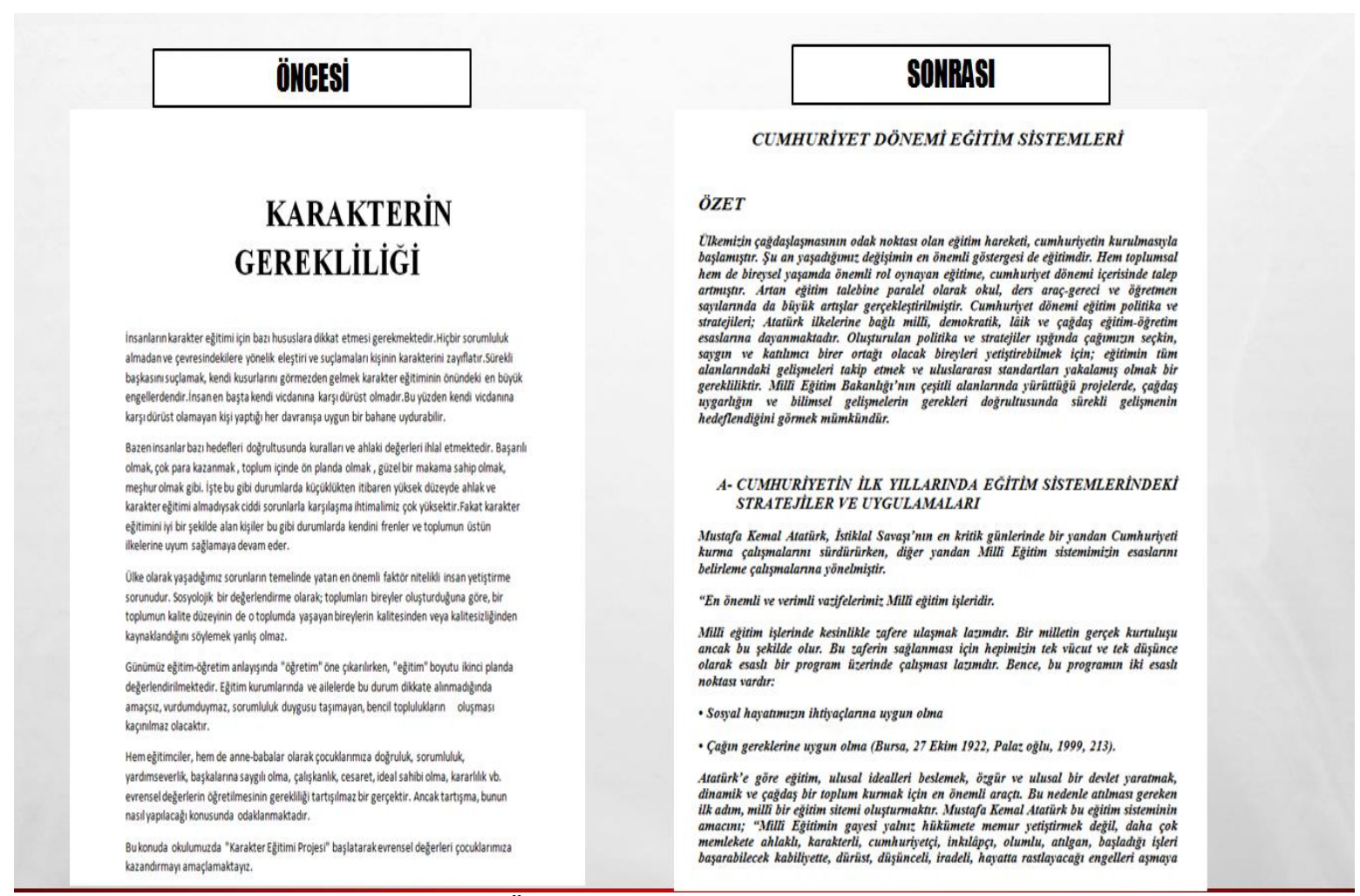

Fotoğraf 2. Öğrencilerden gelen uygulama örnekleri.

Yukarıdaki örneklerde de görüldüğ̈̈ gibi uygulama öncesinde öğrenciler tek kaynağa bağlı kalıp bunu kendilerine ait gibi gösterirken, uygulama sonrasında daha çok kaynaktan yararlanarak yararlandıkları kaynaklara kanıt gösterdikleri görülmüştür. Uygulama sonrasında tüm örnekler burada yer almasa da hazırlanan raporların hem şekil hem de içerik yönünden zenginleștiği fark edilmiştir. Yapılan araştırmaların kusursuz ve eksiksiz olduğu sonucuna ulaşmak mümkün görünmese de öğrencilerin kanıt kullanma konusunda yaşadıkları gelişim aşikârdır.

\section{Bilimsellik değeri etiğe ilişkin bulgular}

Bilimsellik değeri altında önemli kabul edilen ve daha önce öğrencilerin ön bilgilerini ortaya çıkarmak amacıyla yapılan etkinliklerde eksikliği gözlenen bir diğer konu etiktir. Bilim sürekli ilerleme gösteren bir yapıya sahiptir. Her bilimsel çalışma daha önce yapılan araştırmalar üzerinde şekillenmektedir. Bu özelliği dolayısıyla yapılan çalışmaların aktarımında bazı kurallara uyulması ve yararlanılan kaynakların belirtilmesi esastır. Kanıt kullanma ile paralel ilerlediği düşünülen bilimsel araştırmalarda etik konusu, kullanılan kanıtların belirtilmesi işidir. Üniversitede ve birçok eğitim kurumunda ne yazık ki etik konusunda bazı eksiklikler bulunmaktadır. Araştırmacı çalışma grubunda belirlediği bu eksiklikleri gidermek amacıyla bazı etkinlikler yapmaya karar vermiştir. Araştırmacı tarafından belirlenen bilimsel araştırmalarda etik konusuna ilişsin kazanımlar Tablo 6'da gösterilmiştir.

Tablo 6.

Bilimsellik değeri etik konusuna iliş̧kin kazanımlar

Kazandırılmak İstenen Değer: Bilimsellik

Kazanımlar

1. Etiğin ne demek olduğunu bilir.

2. Bilimsel çalışmalarda etiğin gerekliliğini fark eder.

3. Yapmış olduğu çalışmalarda etik ilkelere dikkat eder.

4. Araştırmalarında etik kurallara uymayı davranış haline getirir.

Araştırmacı, kazanımlara ilişkin belirlediği basamaklar doğrultusunda etkinliklerini planlamıştır. Etkinliklerin kanıt kullanma kazanımıyla ortak olduğu düşüncesiyle "Kanıt Kullanma ve Etik" olarak ortak etkinlik biçiminde tasarlamıştır. Etkinlikler planlanırken öğrencilerin ön bilgilerini değerlendirmek amacıyla yapılan çalışmalardan öğrencilerin etik ilkelere dikkat etmediği sonucuna varılmıştır. Bu dikkatsizliğin öğrencilerin bu konuda bilgi sahibi olmamasından $\mathrm{m} ı$ yoksa bilmelerine rağmen uygulamak istememesinden mi kaynaklandığına ilişkin araştırmacı gözlemlerini günlüğüne şu sözlerle ifade etmiştir. 
...Öğrencilerden topladı̆̆ım raporları incelediğimde hepsinde gördüğ̈̈m ortak sorunlardan biri alıntı ve kaynakça eksikliğiydi hatta öğrencilerin hiç alıntı yapmamış olmalarıydı. Öğrencilere bu konuda birkaç soru sordum ve hiçbir bilgilerinin olmadığını fark ettim. Bu konunun üniversite düzeyine gelene kadar ihmal edilmiş olması gerçekten şaşırtıcı bir durum (A.G.08.10.2015).

Araştırmacı, gözlemlediği sorunları gidermek için ilk olarak TUBİTAK (2006) tarafından bilimsel çalışmalarda görülen etik ihlalleri içeren bir sunum hazırlamıştır. Hazırlanan sunumun içeriğini intihal, çarpıtma, yazar adında değişiklik yapma ve duplikasyon gibi konular oluşturmaktadır. Öğrencilerle tartışarak ve görüş alışverişi içerisinde sunumunu gerçekleştiren araştırmacı sunum sonrasında öğrencilerin bu konuya olan ilgilerinin yüksek olduğu kanısına varmıştır. Düşüncelerini günlüğünde belirten araştırmacının değindiği noktalardan birkaçı aşağıdaki gibidir.

Bugün ögrencilere bilimsel araştırmalarda etik ilkelere ait bazı hususları içeren bir sunum yaptım. Özellikle intihal konusuyla öğrencilerin çok ilgili olduğunu gördüm. Öğrenciler arasında çok sık yapıldı̆̆ını ve bilgi hırsızlı̆̆ ile eş değer olduğunu ve bu durumun suç olduğunu duyan öğrenciler sanki biraz daha telaşlandılar. Öğrencilerin yaptıkları çalışmaların intihal programları aracılı̆̆ıla kontrol edildiğini söyleyince sanırım telaşlarını bir kat daha artırmış oldum (A.G. 09.10.2015).

Öğrenciler intihal konusuna vermiş oldukları önemi dersten sonra yazdıkları günlüklerde de göstermişlerdir. Öğrenci günlüklerinden birkaçı aşağıdaki gibidir.

Dersten önce ben intihali bilmiyordum hele ki hırsızlık olduğunu hiç bilmiyordum. Benim için çok iyi oldu. Hocaların hepsi ödev veriyorlar ve bu dediklerime dikkat ediyorlar benim için çok iyi oldu (Gonca, 09.10.2015).

İntihal konusuna öğrencilerin bu kadar önem vermesinin nedeninin intihalin hırsızlıkla eş değer tutulmasından kaynaklandığ 1 düşünülmektedir. Yine öğrenciler arasında yayılan -her hoca bu programa ödevleri sokuyormuş dikkat etmeliyiz söylentileri kazanımları gerçekleştirme noktasında araştırmacıya faydalı olmuştur. Öğrencilerle yapılan bu görüşmelerden birkaçı aşağıda verilmiştir:

Araştırmacı: Merhaba Sabri. Bugün Karakter Ĕ̆itimi Programı çerçevesinde bazı etkinlikler gerçekleştirdik... Senin programda en çok ilgini hangi konu çekti?

Sabri: Programda ben ilk defa duyduğum bilmediğim bir kelimenin anlamını ögrendim mesela. Intihal... Bizler kolaya kaçan insanlar, ögrenciler olduğumuz için başkalarının fikirlerini, eserlerini kendimizin gibi gösteriyorduk. Önceden bunun suç olduğunu bilmiyorduk. Karakter eğitimi programıla beraber bunun büyük bir suç olduğunu ögrendik (0.35"-01.20").

Öğrencilerle yapılan görüşmeler ve öğrencilerin günlüklerinde belirttikleri ifadelere göre öğrencilerin etik konusuna önem verdikleri görülmektedir. Araştırmacı öğrencilerin öğrendikleri bilgileri davranış haline getirmelerini sağlamak amacıyla ortak olarak belirlenen bir konuda uygulamalı etkinlik gerçekleştirmiştir. Öğrencilerden öğrendiklerini bilimsel çalışmalarda uygulayıp uygulamadığını görmek amaçyla araştırma öncesinde ve sonrasında olmak üzere iki ayrı rapor hazırlamaları istenmiştir. Araştırmacı hazırlanan raporları analiz ettikten sonra öğrencilerde bir değişim olup olmadığını belirlemeye çalışmıştır. Öğrencilerden gelen raporlardan birkaçı aşağıdaki gibidir: 


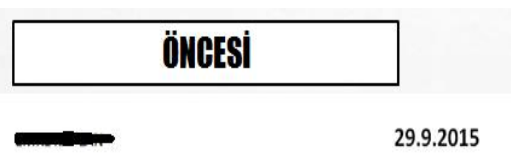

EĞiTiMdE KARAKTER EĞITiMİ GEREKLiLì̆̈i

Devletler eğitim politikalarıı düzenlerken nitelikli eleman yetiştirmenin yanı sıra aynı zamanda erdemli davranış̧ar sergileyebilen toplumsal değerlere uyum sağlayabilen vatandaş̧arda vetiştirmek isterler ve eğitim politikalarııı buna göre düzenlerler. Hatta ve hatta divebiliriz ki iy karakter eğitimi niteliksel ve mesleksel eğitimden daha öncelik ve önem arz etmektedir.

Karakter eğ̈timinin mesleksel eğ̈timden onnemli ve önce olmasinnn sebebini baz örneklerle șu șekilde ele alabilitriz; bir is adamı düșünelim yapttöı ișlerde devletten vergi kaçran ya da bir memur

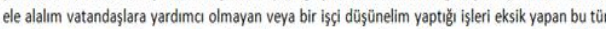
örnekler günümüzde kolayca karşslaşabileceğimiz, maalesef gerekli karakter ve erdem eğitimi verilmedigi için aslinda topluma ve devlete yararindan fazla zararı olan örneklerdir.

Ë̈ritim metodları düzenlenirken öncelik insan yetiştirmek üzerine olmall yani toplumda yardimlaşan, ivi ahlakl, işini düzzün yapan ve buna benzer ozzellikleri daha küçük yaşlardan itibaren

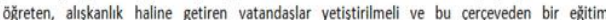
dürenlenmelidir.

Bizlerde ve devlet ve toplum olarak bu anlamda yașanan olaylar gōstermektedir ki eksik kalmıs gözükmekteviz. Cumhuriyet tarihimizde öğretim öne alinıp terbive kısmı bir miktar ihmal edillmiştir. Bu ihmaller toplumumuzda daha büyük sorunlara yol açmıs önemli yerlerde önemli ișler yapan kişsilerin sergilediği gayri ahlaki davranış ve ișler büyük zararlar doğurmus toplumsal güven kaybı yaşatmısțtr.

Elbette karakter eğitimi sadece okullarda olmayip aslında adeta bir kültürün ve geleneğinde devamıdr. Bizler astinda ailemizde ve toplumumuzda da bir çok erdemi ögrenir ve yaşam biçimi haline getiririz. Karakterli bir toplum aynı zamanda devamı olarak karakterli bir nesilde ortaya koyacaktir. Toplum bu küttürü kazandis̆ taktirde de arkadan sürekli karakterli nesiller yetismeye devam edecektir ki bu anlamda verilen eğitim aynı zamanda bir miras olarak gelecek kuşaklara da verilmiş olacaktır.

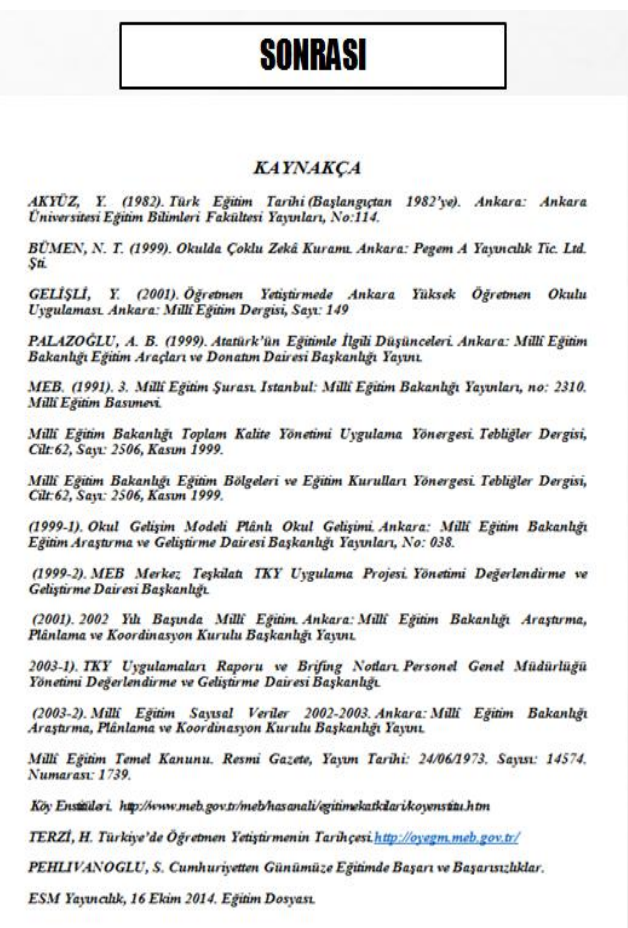

Fotoğraf 3. Öğrencilerden gelen uygulama örnekleri

Araştırmacı, öğrencilerden gelen ilk raporları analiz ettiğinde öğrencilerin metin içinde alıntı kullanmadıkları, ayrıca çalışmalarında kaynakçaya yer vermedikleri sonucuna ulaşmıştır. Uygulama sonrasında gelen ödevler incelendiğinde öğrencilerin raporlarında gözle görülür bir iyileşmenin olduğu görülmektedir. Hemen hemen her öğrenci yaptıkları çalışmalarda alıntılar kullanmış ve metin sonunda kullanmış oldukları alıntılara ait kaynakçaları belirtmişlerdir. Öğrencilerin raporları yüksek lisans doktora seviyesinde olmasa da eski çalışmalarına göre çok daha iyi düzeydedir ve gelişme göstermiştir.

\section{Bilimsellik dĕ̆eri yaratıcılı̆̆a ilişkin bulgular}

Yaratıcılık, olaylara farklı bakmak ve daha önce aralarında ilişki kurulmamış nesneler ve olaylar arasında bağ kurmaktır. Bilinenin, alışılmışın dışında yeni ve farklı çözüm yolları kullanarak özgün bir sonuç ortaya çıkarmaktır. Bilim ve bilimsel yöntem hipotezler, önermeler içerdiğinden ve ortaya çıkan ürünler özgünlük gerektirdiğinden yaratıcılık ve yaratıcı bir bakış açısı gerekmektedir.

Tablo 7.

Bilimsellik değeri yaratıcılık konusuna ilișkin kazanımlar

Kazandırılmak İstenen Değer: Bilimsellik

Kazanımlar

1. Yaratıcı düşünmenin önemini bilir.

2. Yeteneklerini kullanarak yeni düşünceler üretir.

3. Özgün ürünler ortaya çıkarır.

Araştırmacı, kazanımlara ulaşmak için bir eylem planı geliştirmiş ve öğrencilerin yaratıcı bir bakış açısı geliştirmelerini amaçlamıştır. Öğrencileri adım adım araştırma yapma ve nasıl makale yazılacağı konusunda yönlendiren araştırmacının amaçlarından biri, öğrencilerin özgün ürünler ortaya çıkarmalarını sağlamaktır. Öğrencilerden Asiye ve Tülin bu süreci şu şekilde ifade etmektedir.

- Makale nasıl bulunur, araştırma nasıl yapılır onu öğrendik. Sanki çok önemli tamamen özgün bir ürün ortaya çıkarmışız gibi mutlu olduk (05.11.2015).

- Makalenin gelişigüzel yazmak için yazılmasından ziyade aşamalarını makale yazarken yararlanacă̆ımı yerleri keşfetmemiz bize çok şey kattı. Bir şeyleri keşfetmek gerçekten güzel bir duygu (05.11.2015).

Öğrencilerin belirttiği ifadeler aynı zamanda kendilerine olan güvenlerinin arttı̆̆ının da bir göstergesidir. Bir sonraki aşamada araştırmacının amacı, öğrencilerin özgün ürünler ortaya çıkarmalarını 
sağlamaktır. Bu amaçla bilgilerin görselleştirilmesi anlamına gelen "İnfografi Oluşturma" ve "Poster Hazırlama" etkinliklerini planlanmıştır.

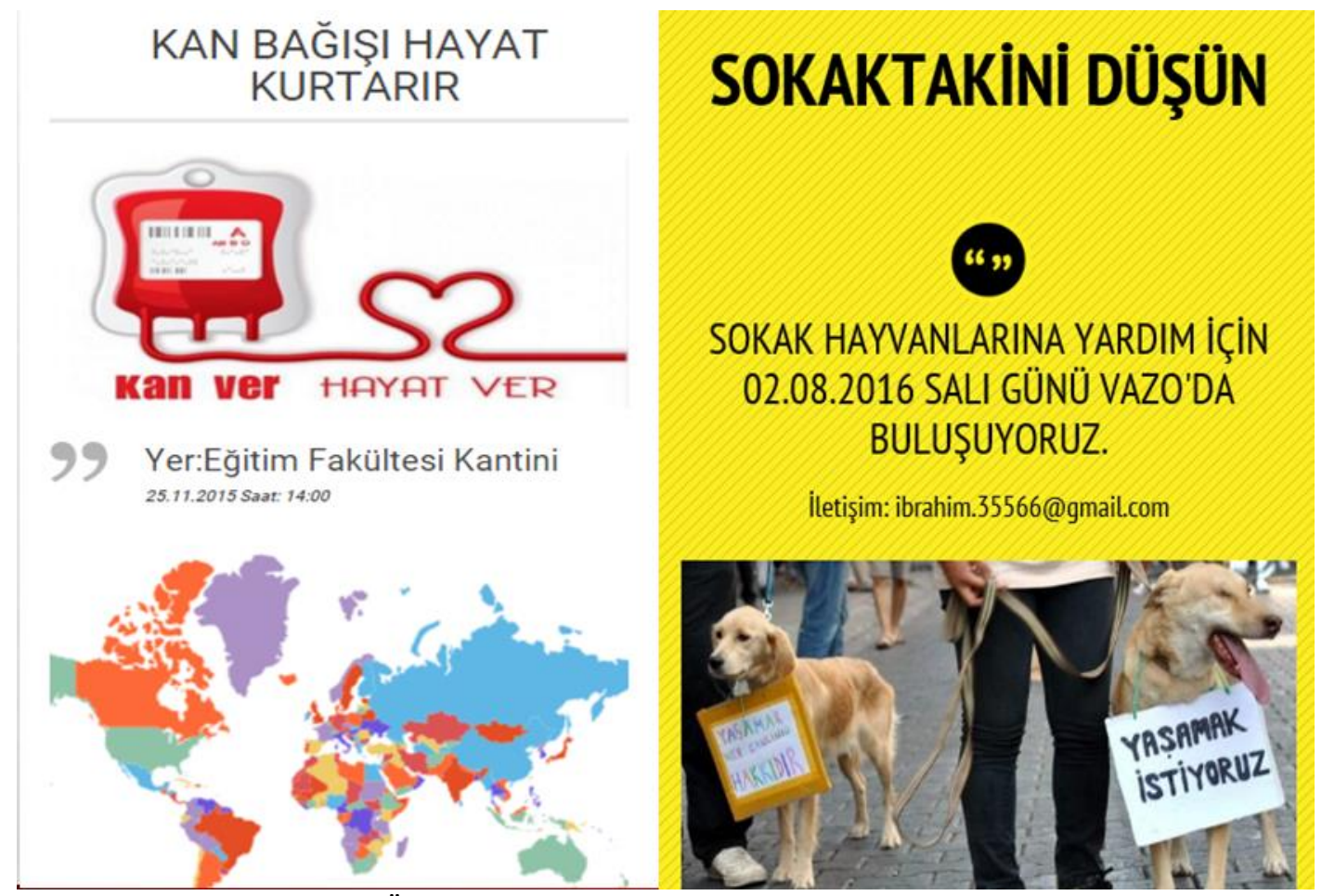

Fotoğraf 4. Ö̆̆rencilerin yaptıkları infografi örneklerinden bazılart.

Araştırmacı, etkinlik sonrasında geçerlilik komitesi üyeleriyle yaptığı görüşmede yapılan etkinliğin eğitime de uyarlanması şeklinde öneri almıştır. $\mathrm{Bu}$ nedenle etkinliğin farklı şekilde yinelenmesi kararlaştırılmıştır. Aynı şekilde ve aynı gruplarla farklı bir günde etkinliği tekrar eden araştırmacı öğrencilerin yaptıkları tekrar sonucu programı daha kolay kullandıklarını fark etmiştir. Araştırmacı bu kez öğrencilerden anlamakta zorlandıkları bir dersin herhangi bir konusunda görseller kullanarak infografi oluşturmalarını istemiştir. Süreç sonunda, öğrencilerin hazırladıkları infografi örneklerinden bazıları aşağıdaki gibidir: 


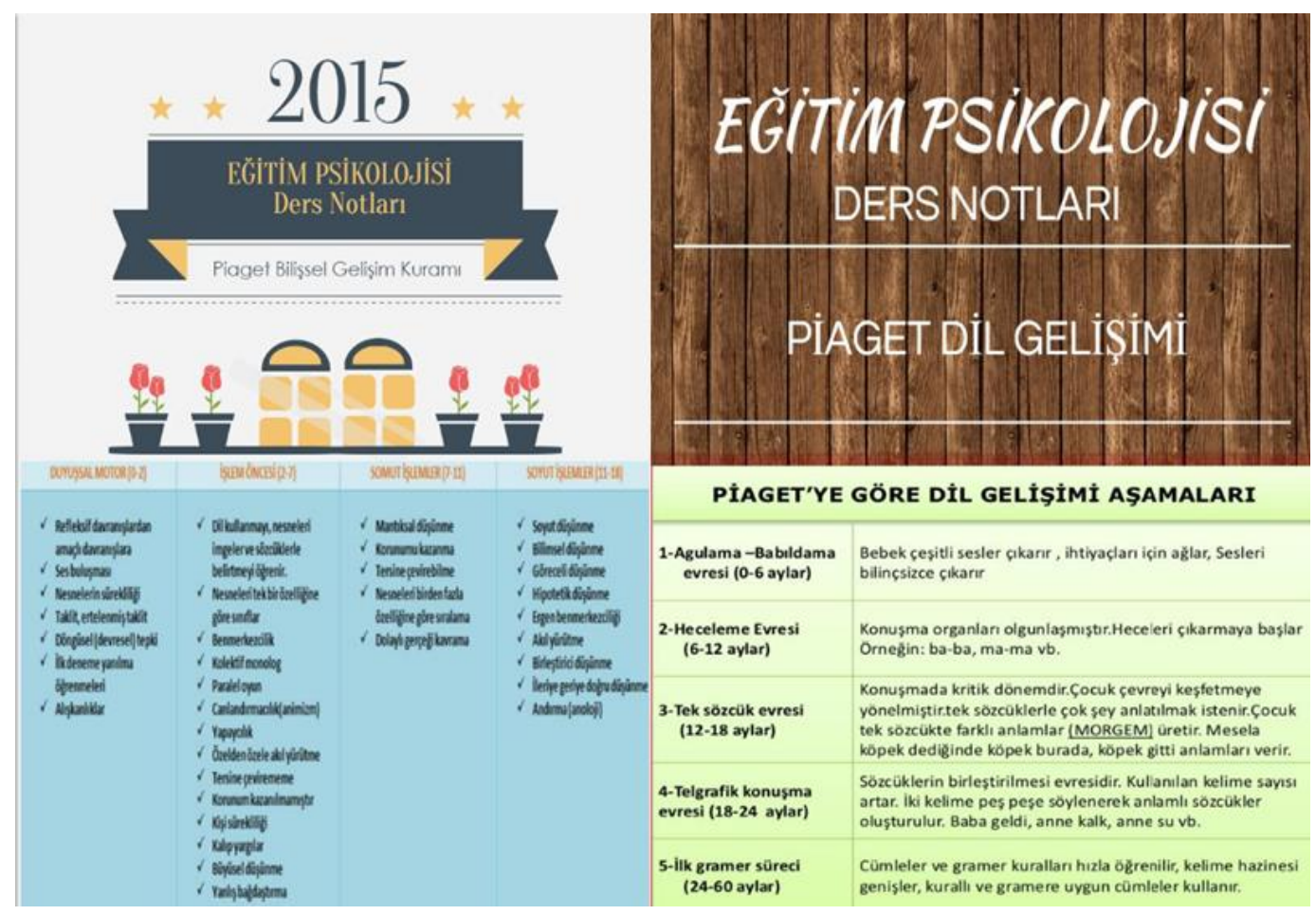

Fotoğraf 5. Öğrencilerin yaptıkları infografi örneklerinden bazıları.

Araştırmacının bilimsellik değeri kapsamında öğrencilerin yaratıcılık becerilerini geliştirmek ve yaratıcı düşünmelerini sağlamak için planladığı etkinliklerden bir diğeri poster hazırlamadır. Bu amacı gerçekleştirmek için ilk olarak bir sunum hazırlayan araştırmacı öğrencilere poster hazırlarken dikkat edilmesi gereken hususları anlatmıştır. Uygulama yaparken öğrencilerden bir kısmının başka bir ders kapsamında da poster hazırlayacaklarını söylemesi üzerine araştırmacı, o dersin öğretim elemanına gidip planlarından ve sürece dâhil olma isteğinden bahsetmiştir. Bunun üzerine planlanan etkinlik dersin hocasıyla koordineli olarak yürütülmüş ve süreç sonunda hazırlanan ürünler fakülte panolarında sergilenmiştir. Öğrenciler poster hazırlama etkinliğini araştırma süreçlerini ve rapor hazırlama etkinliklerini tamamladıktan sonra yapmışlardır. Böylelikle öğrenciler öğrendiklerini hazırlayacakları çalışmalara yansıtmaya çalışmıştır.

Araştırmacının yapmış olduğu planlamanın uygulama planı aşağıdaki gibidir:

Tablo 8.

Etkinlik uygulama planı

Etkinliğe başlamadan önce öğrencilerin bilgisayar laboratuvarına geçmesi sağlanacak ve akademik poster hazırlama kuralları ve poster hazırlarken dikkat edilmesi gereken kurallardan bahsedilecektir. Daha sonra öğrencilerle interaktif olarak bir uygulama yapılacak ve öğrencilerden gelen soru- cevaplara dönüt verilerek konunun anlaşılması sağlanacaktır. Sonrasında sınıf 5'er kişilik gruplara ayrılacak ve her grup çalışmak istediği konuyu belirleyecektir. Öğrencilerden istenen daha önce anlatılanlara bağlı olarak bilimsel bir araştırmayı yürütmek ve poster haline getirmektir. Çalışma için öğrencilere 2 haftalık bir süre tanınacak ve süreç araştırmacı tarafından sürekli olarak takip edilecektir. 2 hafta sonunda öğrencilerin hazırlamasını beklediğimiz 8 poster sunumu araştırmacı desteğiyle öğrenciler tarafından çıktı alınarak okulda sergilenecektir. 3 gün boyunca sergilenecek olan poster sunumları Sosyal Bilgiler Eğitimi Anabilim dalı öğretim üyeleri tarafından çeşitli kriterlere (yönergelere) göre puanlanacak ve 1. olan poster sunum belirlenecektir. Posterlerin sunumu için ilk gün eğitim fakültesi mavi salonda öğretim üyelerinden oluşan bir jüri grubu ve öğrencilerin oluşturduğu bir izleyici kitlesiyle kısa sunumlar yapılacaktır. Süreç sonrasında 1. olan poster sunumu Sosyal Bilgiler Eğitimi alanında yapılacak olan bir kongrede gönderilecektir. Yapılan bu çalışmayla öğrencilerde çalışma ve yaptıkları etkinliğinin sorumluluğunu alma ve bilimsel düşünme becerilerinin de gelişmesi sağlanacaktır.

Araştırmacı, hazırlanan poster sunumlarını değerlendirebilmek için bir puanlama anahtarı hazırlamış ve hazırlamış olduğu bu formu öğrencilerle de paylaşmıştır. Bu form aynı zamanda öğrencileri dikkat etmeleri gereken noktalar konusunda bilgilendirmektedir. 
Tablo 9.

Akademik poster etkinliği puanlama yönergesi

\section{Akademik Poster Etkinliği Puanlama Yönergesi}

Puanlama Yönergesi: Her soru $\underline{10}$ puandan oluşmaktadır ve toplam puan $\underline{100}$ puandır.

\begin{tabular}{lll}
\hline 1 & Poster açık ve kolay okunabilir mi? & 10 \\
\hline 2 & Posterin akış sırası belli oluyor mu? & 10 \\
\hline 3 & Başlık çalışmaya uygun mu? & 10 \\
\hline 4 & Bilimsel bir dil kullanılmış mı? & 10 \\
\hline 5 & Bölüm başlıklarına ve görsellere yer verilmiş mi? & 10 \\
\hline 6 & Sözlü anlatıma gerek kalmadan mesajını aktarıyor mu? & 10 \\
\hline 7 & Yazım ve noktalamaya dikkat edilmiş mi? & 10 \\
\hline 8 & Araştırmacı ilgili çalışmanın içeriğini yeterli seviyede aktarabildi mi? & 10 \\
\hline 9 & Posterde iletişim adresi bulunuyor mu? & 10 \\
\hline 10 & Etik ilkelere dikkat edilmiş mi? (Alıntı, Kaynakça vb.) & 100 \\
\hline TOPLAM PUAN: & \\
\hline
\end{tabular}

Yapılması planlanan posterler tamamlandıktan sonra etkinlik planından farklı olarak dersliklerin olduğu koridorda sergilenmiştir. Planlanan etkinlik başka bir dersin hocasıyla koordineli olarak yürütüldügünnden planlandığı gibi yarışma yapılamamıştır. Etkinlik tamamlandıktan sonra öğrencilerin oluşturdukları poster örneklerinden birkaçı aşağıdaki gibidir:

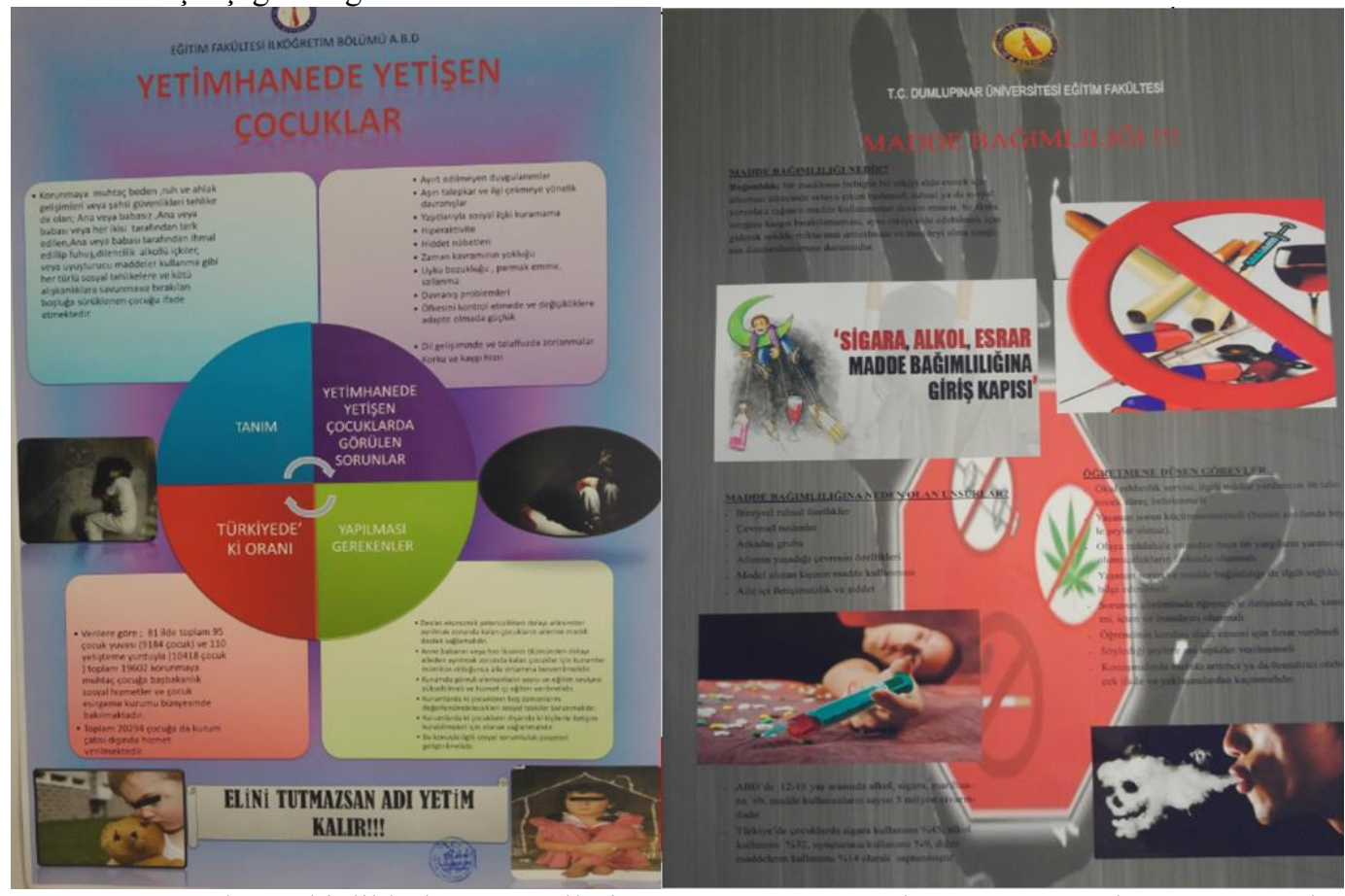

Araştırmacı, bu etkinliklerle öğrencilerin araştırma yaparak özgün ürünler ortaya çıkarmasını hedeflemiştir. Farklı basamaklarda gerçekleştirilen etkinlikler sonrasında öğrencilerden bazıları duygularını aşağıdaki gibi ifade etmektedirler.

Infografi hazır grafikler olarak adlandırıldı̆̆ hazırlamada yardımc olacak bir çalışma. Benim için yeni bir yöntemi öğrenmem iyi oldu. Yeni bir şeyler öğrenmek iyidir ve yaratıcılık sağlar. Hocamızla beraber infografi hazırladığımızda çıkan sonucun çok güzel olduğunu gördüm (Ebru, 12.11.2015).

Infografi oluştururken dikkat edilmesi gerekenleri ve daha güzel infografi nasıl oluşturulur onu ögrendim. Önceden bu programın adını bile duymamıştım. Infografi sayesinde ödev kapă̆l, dergi kapă̆ hazırlayabilirim diye tahmin ediyorum. Yaratıcılı̆̆ımı artırdı̆̆ına inanıyorum (Ayhan, 12.11.2015). 
Tüm bu etkinlikler sonrasında öğrencilerin yeni düşünceler üretmede istekli oldukları, özgün ürünler ortaya çıkarmaya çalıştıkları, hayallerini çalışmalarına yansıtmaya çalıştıkları ve bu yaptıkları çalışmalardan mutluluk duydukları söylenebilir.

\section{SONUÇ, TARTISYMA VE ÖNERILER}

Araştırma sonuçlarına göre, karakter eğitimi programı öğrencilerin bilimsellik değer algılarını olumlu ve anlamlı yönde etkilemektedir. Bilimsellik değeriyle ilgili yapılan etkinliklerde, öğrencilerin hedeflenen kazanımlara ulaşmada başarılı oldukları görülmüştür. Araştırmanın bu bulgusu Katılmış (2010) ve Balcı'nın (2008) yapmış oldukları çalışmaların "Karakter eğitimi ve değer eğitimi programları öğrencilerin bilimsellik değer düzeylerini olumlu yönde etkilemektedir" bulguları ile örtüşmektedir. Bilimsellik değeri kapsamında öğrenciler, "Kanıt Kullanma", "Etik" ve "Yaratıcılık" boyutlarında belirlenen kazanımları gerçekleştirmişlerdir. Katılmış (2010) tarafından hazırlanan karakter eğitimi programında öğrencilere kazandırılması amaçlanan "Bilimsellik Değeri" alt boyutları olarak "Merak Etme ve Eleştirel Bakabilme", Kanıt Kullanma ve Etik" ve "Özgürlük" boyutları belirlenmiştir. Yine Baysal, Kaya ve Üçüncü (2013) tarafından yapılan araştırmada, bilimsellik değeriyle ilgili etkinliklerin bireylerin yaratıcılık düzeylerini olumlu yönde etkilediği sonucuna ulaşılmıştır. Araştırma sonuçlarına göre öğrencilerin özgün makale yazmaları, poster ve infografi örnekleri oluşturup bunları sergileri onların yaratıcılıklarını geliştirmektedir. Öğrencilerin bu yöndeki ifadeleri doğrudan alıntılarla desteklenmektedir.

Köse (2015) karakter eğitimi değerlendirme yöntemi olarak; yansıtıcı günlükler, tartışma etkinlikleri, sınıfta yazma etkinlikleri, gözlem ve görüşmeleri kullanmanın etkili olduğunu belirtmektedir. Öğrencilerin ön bilgilerinin tespit edilmesi aşamasında izlenen yol ile Köse'nin (2015) bulgularıyla benzerlik göstermektedir. Araştırmada öğrencilerin bilimsellik değeriyle ilgili ön bilgilerinin yoklanması aşamasında hazırlıksız olarak verilen araştırma projeleri, öğretim elemanlarıyla yapılan görüşmeler, öğrencilerle yapılan tartışmalar ve araştırmacı gözlemleri etkili olmuştur.

Araştırmada öğrencilerin "Kanıt Kullanma ve Etik" boyutunda problem yaşadıkları sonucuna varılmıştır. Yaptıkları çalışmalarda tek kaynaktan yararlanan ve yararlandıkları kaynakları belirtmeyen, alıntı kurallarına dikkat etmeyen öğrencilerin, etkinlikler sonunda bu noktalardaki eksikliklerini kapatmaya çalıştıkları görülmüştür. Ersoy ve Özden (2011) tarafından gerçekleştirilen çalışmada; öğrencilerin yaptıkları usulsüzlüklerin öğretim elemanları tarafından teftiş edilmesinin internetten aşırma yapma davranışını kontrol altına almada etkili bir faktör olacağından bahsedilmektedir. Reetz ve Jacops (1999) üniversitelerin bilimsel etik konularına yönelik politikalar saptadığından ancak bu politikalara üniversite misyonlarında ve ilkelerinde yer verilmediğinden bahsetmektedir. Öğrencilerin kanıt kullanma ve etik boyutunda yaşadıkları problemler bu yönleriyle Ersoy ve Özden (2011), Reetz ve Jacops’ın (1999) çalışmalarıyla kısmen benzerlik göstermektedir. Sorgulamaya dayalı etkinliklerin yapıldığı araştırmada, bilginin kaynaklarını öğrenmenin ve sorgulamanın eleştirel düşünmeyi olumlu yönde etkilediği bulgusuna ulaşılmıştır. Yine Arthur'un (2008) "karakter eğitiminde eleştirel düşünmeyi içeren stratejiler kullanılmalıdır" ve Doğanay'ın (2009) "bilişsel süreçlerin işleme konulmasında problem çözme ve eleştirel bakabilme gerekmektedir" ifadeleriyle de benzerlik göstermektedir.

Bilimsellik değeri kapsamında yapılan poster ve infografi çalışmaları, öğrencilerin araştırma basamaklarını ve hayal güçlerini kullanarak ortaya çıkardıkları özgün ürünler, öğrencilerin yaratıcı bakış açısı kazanmalarını olumlu yönde etkilemektedir. Araştırma bulguları, Baysal, Kaya ve Üçüncü (2013), Aktamış ve Ergin'in (2007) araştırma sonuçlarıyla örtüşmektedir. Aktamış ve Ergin'e (2007) göre bilimsel yaratıcılık; yeni bir ürün ortaya koyma ya da var olan bir ürünü geliştirirken hangi basamakların kullanıldığına yani problemin nasıl çözüldüğüne ve problemin nasıl fark edildiğine bağlıdır. Yeni bir ürün ortaya koyarken araştırmada bilimsel araştırma basamaklarının kullanılması bu yönüyle Aktamış ve Ergin'in (2007) bulgularıyla kısmen örtüşmektedir.

Araştırmada karakter eğitimi programının öğrencilerin bilimsellik değeri için gerekli olan tutum, bilgi ve davranışları edinmede olumlu etkiye sahip olduğu bulunmuştur. Araştırmanın bu sonucu değerler eğitiminde karşılaşılan en önemli sorunlardan biri olarak görülen sadece bilgi boyutunun esas alınıp tutum ve davranış boyutlarına yer verilmemesinin yanlışlığını belirten Güngör'ün (2010) bulgularıyla örtüşmektedir.

Genel olarak değerlendirildiğinde, araştırma sonucunda ulaşılan bulgular, alan yazında yapılan çalışmalarla karşılaştırıldığında yapılan diğer çalışmaların sonuçlarıyla büyük oranda örtüştüğü söylenebilir.

Araştırmadan elde edilen bulgular bağlamında aşağıdaki öneriler getirilebilir:

- Üniversite düzeyinde karakter eğitimi için gerekli olan yöntem ve uygulamalar hakkında ortak bir anlayış söz konusu değildir (Jones, Ryan ve Bohlin, 1998; Milson, 2000). Bu sebeple karakter eğitimiyle ilgili yükseköğretim düzeyinde yapılan uygulamaların sayısı artırılabilir. 
- Bilimsellik değeri kapsamında yapılan poster ve infografi yarışması gibi farklı çalışmalar öğrencilerin yaratıcı bakış açısı kazanmalarını olumlu yönde etkilemektedir Öğrencilerin çalışma becerilerini ve bilimsel bakış açılarını olumlu yönde etkileyebilmek için bunun gibi çeşitli yarışmalar düzenlenebilir.

- Öğretmenler adaylarıyla gerçekleştirilen bu araştırmada öğretmen adaylarının değer ve karakter eğitimiyle ilgili bilgi ve uygulama aşamasında eksiklikleri olduğu görülmüştür. Öğretmen adaylarında görülen bu eksiklerin giderilmesi için ilgili alanlarda planlama, yöntem ve etkinlik hazırlamaya yönelik özel eğitim verilebilir.

\section{KAYNAKÇA}

Ada, S. ve Ünal, S. (2000). Sinıf Yönetimi. İstanbul: Marmara Üniversitesi Teknik Eğitim Fakültesi Yayınları.

Ada, S., Baysal, Z. N. \& Korucu, S. (2005). Sınıf öğretmenlerinin sınıf içi olumsuz davranışlara gösterdikleri tepkilerin karakter eğitimi ve 2005 ilköğretim programı açısından değerlendirilmesi. Değerler Eğitimi Dergisi, 3 (10), 7-18.

Aktamış, H. ve Ergin, Ö. (2007). Bilimsel süreç becerileri ile bilimsel yaratıcılık arasındaki ilişkinin incelenmesi. Hacettepe Üniversitesi Ĕ̈itim Fakültesi Dergisi, 33, 11-23.

Arthur, J. (2008). Traditional approaches to character education in Britain and America. In L. P. Nucci \& D. Narvaez (Eds.), Handbook of Moral and Character Education (pp. 80-98). New York ve London: Routledge, Taylor ve Francis Group.

Bacanl1, H. (2002). Psikolojik kavram analizleri. Ankara: Nobel Yayınları.

Balcı, N. (2008). Illköğretim 6. sinıf sosyal bilgiler dersinde değerler eğitiminin etkililiği. Yayınlanmamış Yüksek Lisans Tezi, Marmara Üniversitesi Eğitim Bilimleri Enstitüsü, İstanbul.

Battistich, V. A. (2008). Character education, prevention and positive youth development. Journal of Research in Character Education, 6 (2), 81- 90.

Baysal, Z. N., Kaya, N. B. \& Üçüncü, G. (2013). İlkokul dördüncü sınıf öğrencilerinde bilimsel yaratıcılık düzeyinin çeşitli değişkenler açısından incelenmesi. Eğitim Bilimleri Dergisi, 38, 55-64.

Büyüköztürk, Ş., Çakmak K. E., Akgün, E. A, Karadeniz, Ş. \& Demirel, F. (2010). Bilimsel Araştırma Yöntemleri. Ankara: PegemA Yayıncılık.

Creswell, J. W. (2013). Araştırma Deseni (Çev. S. B. Demir). Ankara: Eğiten Kitap.

Çepni, S. (2012). Araştırma ve Proje Çalışmalarına Giriş. Trabzon: Celepler Matbaacılık.

Dilmaç, B. (2007). Bir grup fen lisesi ögrrencisine verilen insani değerler eğitiminin insani değerler ölçeği ile sinanması. Yayınlanmamış Doktora Tezi, Selçuk Üniversitesi Sosyal Bilimler Enstitüsü, Konya.

Doğanay, A. (2009). Değerler eğitimi. İçinde C. Öztürk (Ed.) Sosyal Bilgiler Öğretimi Demokratik Vatandaşlık Ĕgitimi (s. 225-256). Ankara: PegemYayıncılık.

Ekşi, H. (2003). Temel insani değerlerin kazandırılmasında bir yaklaşım: Karakter eğitimi programları. Değerler Eğitimi Dergisi,1 (1), 79-96.

Ekşi, H. ve Katılmış, A. (2014). Karakter eğitimi el kitabı. Ankara: Nobel Yayınevi.

Ersoy, A. ve Özden, M. (2011). The views of teacher candidates regarding the role of instructor in plagiarizing from internet in their assignments. Elementary Education Online, 10 (2), 608- 619.

Gömleksiz, M. (2007). Lise öğrencilerinin toplumsal değerlere ilişkin tutumları: Elazığ ili örneği. İçinde R. Kaymakcan, S. Kenan, H. Hökelekli, Z. Ş. Aralan ve M. Zengin (Ed.) Değerler ve Eğitimi Uluslararası Sетроzуити Kitabı (s. 727-741). İstanbul: Değerler Eğitimi Merkezi Yayınları.

Güngör, E. (1993). Değerler Psikolojisi. Amsterdam: Hollanda Türk Akademisyenler Birliği Vakfı Yayınları.

Güngör, E. (2010). Değerler Psikolojisi Üzerine Araştırmalar. Ankara: Ötüken Yayınları.

Halstead, M. (1996). Values in Education and Education in Values. Values and Values Education in Schools. London: The Falmer Press. 
Harcar, T. (2005). 2000'li yıllarda Amerikan ve Türk yöneticilerinin bireysel yöneticilik değerlerine ilişkin iki kültür arası karşılaştırmaya yönelik bir araştırma. Yayınlanmamış Doktora tezi, İstanbul Üniversitesi Sosyal Bilimler Enstitüsü, İstanbul.

Hensen, K. T. (1996). Teachers as researchers. In J. Sikula (Ed.), Handbook of Research on Teacher Education (2nd ed., pp. 53-66). New York: Macmillan.

Johnson, A. P. (2002). Short Guide to Action Research. Boston: Allyn\& Bacon.

Jones, E. N., Ryan, K., \& Bohlin, K. (1998). Character education and teacher education: How are prospective teachers being prepared to foster good character in students? Action in Teacher Education, 20, 11-28.

Kalaycı, Ş. (Ed.) (2005). SPSS Uygulamalı Çok Değişkenli İstatistik Teknikleri. Ankara: Asil Yayın Dağıtım Ltd.Şti.

Katılmış, A. (2010). Sosyal bilgiler dersindeki bazı değerlerin kazandırılmasına yönelik bir karakter ĕğitimi programının geliştirilmesi. Yayınlanmamış Doktora tezi, Marmara Üniversitesi Eğitim Bilimleri Enstitüsü, İstanbul.

Keskin, Y. ve Öğretici, B. (2013). Sosyal bilgiler dersinde “duyarlılık” değerinin etkinlikler yoluyla kazandırılması: Nitel bir araştırma. Değerler Eğitimi Dergisi, 11 (25), 143-181.

Kılınç, M. (2011). İlköğretim Hayat Bilgisi programı karakter ĕgitimi boyutunun öğrencilerin tipik performanslarına dayalı olarak değerlendirilmesi: Kırşehir örneği. Yayınlanmamış Doktora Tezi, Atatürk Üniversitesi Eğitim Bilimleri Enstitüsü, Erzurum.

Kıncal, R. (1999). Öğretmenlik Mesleğine Giriş. Erzurum: Eser Ofset.

Kirschenbaum, H. (1995). 100 ways to enhance values and morality in schools and youth settings. Massachusetts: Allyn\&Bacon Company.

Köse, Ç. T. (2015). Ergenler için karakter eğitimi: Bir araştırma merkezine ilişkin durum çalışması. Ĕğitim ve Bilim, 40 (179), 295- 306.

McTaggart, R. (2002). Reading the collection. In R. McTaggart (Ed.) Participatory Action Research (pp. 1- 12). Albany, NY: Suny Press.

MEB. (2005). Illkögretim Sosyal Bilgiler Dersi 4-5 Sınıf Öğretim Programı ve Kılavuzu. Ankara: MEB Yayınları.

Mills, G. E. (2003). Action Research: A Guide for the Teacher Researcher. (2nd ed.), New Jersey: Merrill Prentice Hall.

Milson, A. J. \& Mehling, L. M. (2002). Elementary school teachers' sense of efficacy for character education. The Journal of Educational Research, 96 (1), 47-53.

Milson, A. J. (2000). Creating a curriculum for character development: A case study. The Clearing House, 74 (2), 89-93.

Montagu, A. (2000). Çocuklarınıza Ahlaki Değerleri Nasıl Kazandırabilirsiniz? İstanbul: MEB Basımevi.

Öncül, R. (2000). Eğitim ve Eğitim Bilimleri Sözlüğü. İstanbul: Milli Eğitim Basımevi.

Özensel, E. (2003). Sosyolojik bir olgu olarak değer. Dĕgerler Ĕ̆itimi Dergisi, 1 (3), 217-239.

Patterson, L. \& Shannon, P. (1993). Reflection, inquiry, action. In L. Patterson, C. Santa, K. Short, \& K. Smith (Eds.). Teachers are Researchers: Reflection and Action. Newark, DE: International Reading Association.

Patton, M. Q. (1990). Qualitative Evaluation and Research Methods (2nd ed.). Newbury Park, CA: Sage.

Reetz, L. J., \& Jacobs, G. M. (1999). Faculty focus on moral and charactereducation. Education, 120 (2), 208 212.

Rokeach, M., (1973). The nature of human values. New York: The Free Press.

Ryan, K. (1992). The moral education of teachers. In. T. Lickona \& K.Ryan (Eds.) Character Development in Schools snd Beyond (pp. 287-304). Washington. 
Sılay, N. (2010). Yükseköğretimde karakter eğitiminin incelenmesi. Yayınlanmamış Doktora Tezi, Marmara Üniversitesi Eğitim Bilimleri Enstitüsü, İstanbul.

Şişman, M. (2002). Eğitimde Mükemmellik Arayışı; Etkili Okullar. Ankara: Pegem A Yayıncılık.

Thornton, S. J. (1991). Teacher as curricular-instructional gatekeeper in social studies. In J. P. Shaver (Ed.), Handbook of Research on Social Studies Teaching and Learning (pp. 237-248). New York: Macmillan.

Tozlu, N. \&Topsakal, C. (2007). Avrupa Birliğine Uyum Çerçevesinde Değerler Ĕgitimi. İstanbul: DEM. Yayınları.

Ural, S. (1997). Bireyin eğitimi ve toplumun eğitimi (Değerler ve eğitim arasındaki mantıksal ilişki). Türkiye 2. Ĕgitim Felsefesi Kongresi Bildiriler Müzakereler: Van Yüzüncü Yıl Yayınları.

Yavuzer, H. (1999). Çocuk Psikolojisi. İstanbul: Remzi Kitapevi.

Yıldıım, A. ve Şimşek, H. (2008). Sosyal Bilimlerde Nitel Araştırma Yöntemleri. Ankara: Seçkin Yayıncılık. 


\title{
Development of Teacher Candidates' Perceptions of Scientific Value Through Character Education Program: An Action Research
}

\author{
Hafize ER TÜRKÜRESIN \\ Dumlupinar University, Kütahya/TÜRKIYY \\ hafize.er@dpu.edu.tr
}

Citation: Er Türküresin, H. (2018). Development of Teacher Candidates' Perceptions of Scientific Value Through Character Education Program: An Action Research. E-Kafkas Journal of Educational Research, 5(2), 1-19.

\section{Extended Summary}

Introduction: Values are our standards and principles for judging worth. They are the criteria by which we are judge 'things'(people,objects, ideas, actions and situations) to be good, worthwhile and desirable; or on the other hand, bad, worthless, despicable (Halstead, 1996). Values exist as a result of the interaction between individuals and society. What society expects from education is to provide individuals with knowledge and skills as well as to become moral individuals that can adapt rapidly to changing world. Providing each individual who is at the age of education with values and skills, which would help these individuals to display appropriate ethical judgements and behaviours, is inevitably among the main objectives of the schools (Ekşi, 2003; Keskin \& Öğretici, 2013). Recent research shows that teacher-training institutions are supporting teachers to prepare for character education. For this reason character and value education seem important (Ada, Baysal \& Korucu, 2005). However, there is no common understanding of the methods and practices required for character education at university level. The purpose of this study is to determinate the effect of the character education program on scientific value. To find the answer to this problem, the following questions have been asked;

- Does the character training program affect the science-value perceptions of teacher candidates?

- How the character education program is to determinate the effect teacher candidates ' scientific value perceptions?

Method: This study is figured by action research which is often used in qualitative researches. The action research method, which allows researchers to use theory and practice together, was implemented in order to improve pre-determined characteristics. Action research is an orientation to knowledge creation that arises in a context of practice and requires researchers to work with practitioners. The research is conducted with 21 participants who were students in Dumlupınar University, Social Studies Teacher Education Program in 20152016 school year. However, 6 boys and 5 girls who met the specified criteria were selected as the focus and only the focus students were evaluated. Criterion sampling of purposeful sampling methods was used or determining focus participants The data gathered from video recordings, semi-structured interviews, researcher and participant journals, students' outputs and "Being Scientific Scale". In an action research, analysis is carried out during the data collection process, and it sheds light on the type and quality of the additional data which needs to be collected. SPSS 20.0 was used for analyizing the quantitative data and NVivo 9.0 was used for analyizing qualitative data. Gualitative data's, obtained at the end of the research, are analyzed according to descriptive analysis.

Findings, Discussion and Recommendations: The results from quantitative data show that the students scores increased in scale. Findings from qualitative data support quantitive findings. The data which was acquired after the activities shows that the activities of value education have had a positive effect on students' scientific values level. Moreover, the results show that the character education program is effective for charachter development of students. The findings of the study show that the activities related to value education improves the scientific value perception level of the students. This result was supported with the results of studies which were done by Katılmış (2010), Balc1 (2008), Baysal, Kaya \&Üçüncü (2013). 